Article

\title{
Investigating the Potential Role of Geological Context on Groundwater Quality: A Case Study of the Grenville and St. Lawrence Platform Geological Provinces in Quebec, Canada
}

\author{
Roxane Tremblay*(D), Julien Walter $(D)$, Romain Chesnaux and Lamine Boumaiza $(D)$
}

Citation: Tremblay, R.; Walter, J.;

Chesnaux, R.; Boumaiza, L. Investigating the Potential Role of Geological Context on Groundwater Quality: A Case Study of the Grenville and St. Lawrence Platform Geological Provinces in Quebec, Canada. Geosciences 2021, 11, 503. https://doi.org/10.3390/ geosciences 11120503

Academic Editors: Nicolò Colombani and Jesus Martinez-Frias

Received: 7 November 2021

Accepted: 7 December 2021

Published: 9 December 2021

Publisher's Note: MDPI stays neutral with regard to jurisdictional claims in published maps and institutional affiliations.

Copyright: (c) 2021 by the authors. Licensee MDPI, Basel, Switzerland. This article is an open access article distributed under the terms and conditions of the Creative Commons Attribution (CC BY) license (https:/ / creativecommons.org/licenses/by/ $4.0 /)$.
Centre d'Études sur les Ressources Minérales, «Risk Resources Water» (R2eau) Research Group, Département des Sciences Appliquées, Université du Québec à Chicoutimi, Saguenay, Québec, QC G7H 2B1, Canada; julien_walter@uqac.ca (J.W.); romain_chesnaux@uqac.ca (R.C.); lamine.boumaiza@uqac.ca (L.B.)

* Correspondence: tremblayroxane3@gmail.com

Abstract: The hydrogeochemical study of the Lanaudière and Eastern Mauricie regions (Canada) demonstrates that trace elements appear to be better tracers of geological influence on groundwater chemistry than major elements. Isotopic ratios and the similar chemical composition of groundwater suggest that the physicochemical parameters of groundwater have a greater effect on hydrogeochemical mechanisms than the immediate geological environment The results allow us to propose a conceptual model of groundwater geochemical evolution with the aim to guide the protection and sustainable management of regional groundwater resources in the Lanaudière and Eastern Mauricie regions. These regions were selected because of their location at the boundary of the Grenville and St. Lawrence Platform geological provinces, representing two distinct geological contexts (Precambrian crystalline rocks and Paleozoic sedimentary rocks). Regional-scale hydrogeochemical and isotopic groundwater characterization was carried out to identify the role of the differences in regional geology on groundwater quality. Our analyses included major and trace elements, stable isotopes, and multivariate statistics. Similar processes are at the origin of dissolved major chemical elements and suggest that soluble minerals common to both geological provinces control groundwater chemistry. If differences exist, they are due to the hydrogeological conditions of the samples, such as residence time or groundwater entrapment at the time of the postglacial marine incursion of the Champlain Sea, rather than the geological context. Some differences, sometimes significant, were observed for some minor elements $\left(\mathrm{F}^{-}, \mathrm{Mn}^{2+}, \mathrm{H}_{2} \mathrm{~S}\right)$, which implies a more comprehensive knowledge of the chemistry of the stratigraphic units within the Lanaudière and Eastern Mauricie aquifers.

Keywords: conceptual model; groundwater statistics; hydrochemistry; sedimentary rocks; crystalline rocks; Québec

\section{Introduction}

In Quebec, Canada, groundwater represents an economically exploitable source of potable water because of its quality and proximity to sites of its consumption [1]. For several years, hydrogeological data, including borehole logs and groundwater chemical analyses, have been collected by public and private organizations in Quebec. To produce a complete database accessible to hydrogeologists and water managers, the Quebec government implemented the Groundwater Knowledge Acquisition Program in 2008 (Programme d'Acquisition de Connaissances sur les Eaux Souterraines, PACES) under the direction of the Ministère de l'Environnement et de la Lutte contre les Changements Climatiques (MELCC) [1-3]. By the end of this project, approximately two-thirds of the administrative territories of southern Quebec will be characterized hydrogeologically with the aim of rendering the relevant data available for sustainable groundwater resource protection and management. As part of the PACES project, the Centre d'Études sur les Ressources Minérales of the Université du Québec à Chicoutimi (CERM-UQAC) was tasked to compile 
existing hydrogeological information and then expand groundwater knowledge of the Lanaudière and Eastern Mauricie administrative regions of eastern Quebec (Figure 1).

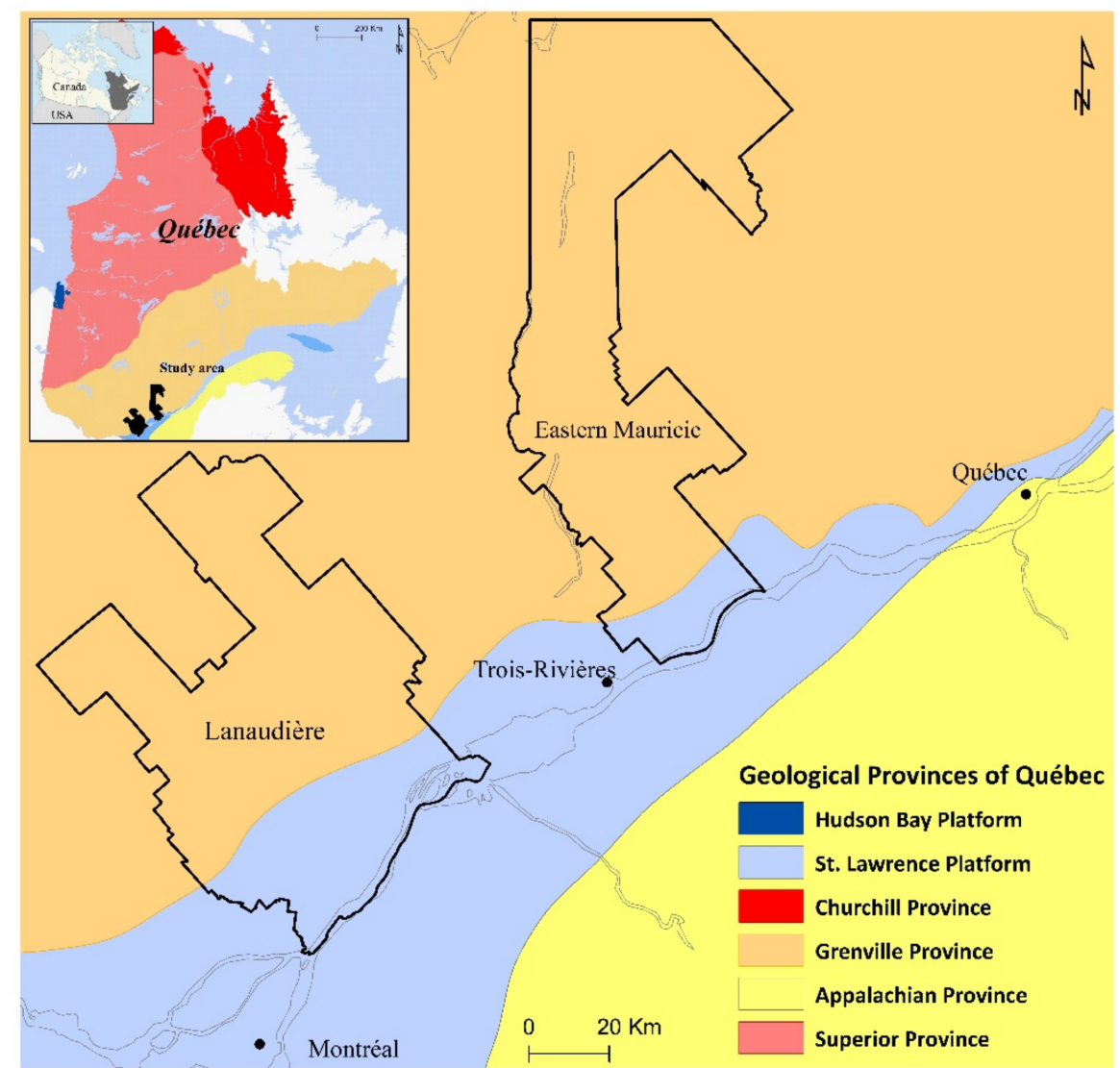

Figure 1. Geological provinces within Quebec (inset) and the location of the study areas of the Lanaudière and Eastern Mauricie administrative regions.

Groundwater is an important geological agent due to (i) its interaction with the ambient environment and (ii) its spatial flowing distribution [4]. Chebotarev and Tòth, for example, observed an increase in total dissolved solids (TDS) from groundwater inflow to outflow areas $[4,5]$. Because the lithologies of aquifers and the groundwater residence time are related to the geological context, groundwater chemistry is expected to differ between geological provinces. Six geological provinces underlie Quebec, i.e., the Hudson Bay and St. Lawrence platforms, as well as the Churchill, Grenville, Appalachian, and Superior provinces (Figure 1). Regional hydrogeochemical characterizations were conducted for the St. Lawrence Platform, Grenville, and Appalachian provinces as part of the PACES program [6-12].

Beaudry et al. [6], Lacasse [10], and Cloutier et al. [12] showed that the Champlain Sea incursion about ca. 11,000 to 13,000 years BP continues to affect groundwater quality in confined aquifers within the St. Lawrence Platform and Appalachian Province. These authors identified two main processes affecting groundwater geochemistry within the St. Lawrence Platform. The first is carbonate dissolution resulting in high concentrations of $\mathrm{Ca}^{2+}$ and $\mathrm{Mg}^{2+}$. The second involves the $\mathrm{Ca}^{2+} / \mathrm{Na}^{+}$cation exchange and mixing with the trapped fossil pore seawater originating from the incursion of the Champlain Sea in southern Quebec; the result is highly saline groundwater (Na-Cl in composition). Multiple investigations of the groundwater chemistry of the Canadian Shield belonging to the Grenville Province identified silicate weathering and $\mathrm{Ca}^{2+} / \mathrm{Na}^{+}$cation exchange as the main processes governing regional groundwater chemistry $[7-9,13,14]$. Montcoudiol et al. demonstrated that water from the postglacial Champlain Sea continued to influence 
groundwater quality at the junction between the St. Lawrence Platform and the Grenville Province [9]. The water-rock interaction between the Grenvillian rocks and groundwater is likely the main process responsible for the elevated concentrations in barium, boron, manganese, and fluorine in deep rock aquifers [8,13].

Most of the above-cited studies have established a conceptual model of the chemical evolution of groundwater of individual geological provinces, although the authors did not evaluate differences in geology among the study regions. The main objective of this study is to investigate the processes and mechanisms governing differences in groundwater chemical composition between two geological provinces, the St. Lawrence Platform, which is composed of sedimentary rocks, and the Grenville Province, which is composed of igneous and metamorphic rocks. The specific objectives are to (1) investigate different processes at the origin of groundwater chemistry and verify whether they are distinct to each geological province and (2) identify those natural contaminants that are spatially correlated with the respective geological provinces.

\section{Materials and Methods}

\subsection{Study Area}

The $11,845 \mathrm{~km}^{2}$ study area includes the Lanaudière and Eastern Mauricie regions, both covering portions of the St. Lawrence Platform and Grenville Province (Figure 1). The southern portion of the regions is dominated by agricultural uses, whereas the northern regions are predominantly forested areas. The urban agglomerations are scattered and consist of mainly residential and commercial areas $[15,16]$. The Lanaudière region has 55 administrative municipalities spread over an area of $5962 \mathrm{~km}^{2}$ with a population (2021) of 346,418 [17]. Eastern Mauricie has 12,387 inhabitants (2021) spread over an area of $5883 \mathrm{~km}^{2}$. The latter region is divided into 22 administrative municipalities [18].

Approximately $80 \%$ of the study area lies within the Grenville Province (Proterozoic), and 20\% lies within the St. Lawrence Platform (Cambrian to Ordovician). The Grenville Province is composed mainly of gneiss (tonalitic and trondhjemitic), paragneiss, and marble. Some zones contain gabbros and metagabbros, whereas other zones in the province are composed of granite and pyroxeniferous monzonites [19-22]. The topography of the Grenville Province includes hills, plateaus, and low-lying areas. The average elevation is $390 \mathrm{~m}$, and the highest point is located around Saint-Donat $(884 \mathrm{~m})$. The hydrographic network of the Grenville area is controlled by the pattern of hills being generally intersected by narrow valleys oriented N-NW/S-SE.

The St. Lawrence Platform corresponds to a succession of sedimentary units. The sediments were deposited initially in horizontal accreted units during the Appalachian Orogeny $[23,24]$. These units include sandstone conglomerates, dolomites, limestone, and shale; they form a complete sedimentary sequence representing a full transgressionregression cycle $[23,24]$. The St. Lawrence Platform corresponds to a low-lying area with an average elevation of $37 \mathrm{~m}$, which slopes gradually toward the St. Lawrence River.

Quaternary materials covering both the Grenville Province and the St. Lawrence Platform were deposited during and immediately following the retreat of the Laurentide ice sheet. Till covers the Grenville Province and is composed of fine to coarse particles produced by erosion of the bedrock. At around 11,000 to 13,000 years BP, the Champlain Sea entered the isostatically depressed St. Lawrence Valley. This marine incursion induced a saltwater recharge under glaciomarine deposits and produced a marine clay aquitard through the deposition of fine silts and marine clays. Fluvioglacial sediments were deposited locally above the glaciomarine deposits and are often found in the St. Lawrence Valley [25].

The regional climate is characterized by six months of cold winters followed by short summers. Average winter temperatures range from -15 to $-5^{\circ} \mathrm{C}$ and vary between 10 and $19^{\circ} \mathrm{C}$ in summer. Rain and snowfall combine for annual total precipitation of $825 \mathrm{~mm} /$ year for the Lanaudière and $752 \mathrm{~mm} /$ year for the Eastern Mauricie regions [26]. 


\subsection{Methodology}

\subsubsection{Groundwater Samples and Laboratory Analyses}

The sampling campaign was conducted during the summer of 2019. A total of 314 groundwater samples were collected, including 231 from the Grenville Province and 83 from the St. Lawrence Platform. Groundwater samples were collected from private drinking wells. Groundwater volume, representing two to four times the volume contained in the well column, had to be purged prior to groundwater sampling to remove standing water [27]. Physicochemical parameters of groundwater-temperature $\left(\mathrm{T} ;{ }^{\circ} \mathrm{C}\right)$, electrical conductivity $(\mathrm{EC} ; \mu \mathrm{S} / \mathrm{cm}), \mathrm{pH}$, redox potential $(\mathrm{Eh} ; \mathrm{mV})$, dissolved oxygen $(\mathrm{DO} ; \%)$, and total dissolved solids (TDS; $\mathrm{mg} / \mathrm{L}$ ) — were monitored in situ during the purging process using a calibrated HANNA portable analyzer. Monitoring continued until three consecutive readings stabilized within $\pm 10 \%$. Groundwater samples were then collected using the appropriate bottles (Table 1). Groundwater samples were filtered in the field through a $0.45 \mu \mathrm{m}$ membrane filter prior to the analysis of metallic ions. Two or three drops of ultrapure nitric acid $\left(\mathrm{HNO}_{3}\right)$ were added to the groundwater samples used for analyzing the major cation and trace element concentrations. Groundwater samples were kept at four degrees Celsius until they were sent to a commercial laboratory (Bureau Veritas Group) for the chemical analyses of inorganic constituents; these analyses included major and minor elements, metals, nutrients, ammonium, and sulfides. Total alkalinity was determined in the field by titration (HANNA-HI3811).

Table 1. Chemical elements analyzed by the accredited laboratory, Bureau Veritas Group.

\begin{tabular}{|c|c|c|c|}
\hline Bottles & Parameters & Preservatives & Filters \\
\hline $\begin{array}{l}\text { Polyethylene } \\
\quad 500 \mathrm{~mL}\end{array}$ & $\begin{array}{c}\text { Suspended solids } \\
\text { Total solids } \\
\text { TDS }\end{array}$ & NA & NA \\
\hline $\begin{array}{l}\text { Polyethylene } \\
\quad 250 \mathrm{~mL}\end{array}$ & $\begin{array}{c}\mathrm{Al}, \mathrm{Sb}, \mathrm{Ag}, \mathrm{As}, \mathrm{Ba}, \mathrm{Be}, \mathrm{Bi}, \mathrm{B}, \mathrm{Ca}, \mathrm{Cr}, \mathrm{Co}, \mathrm{Cu}, \mathrm{Fe}, \mathrm{Li}, \\
\mathrm{Mg}, \mathrm{Mn}, \mathrm{Mo}, \mathrm{Ni}, \mathrm{K}, \mathrm{Pb}, \mathrm{Se}, \mathrm{Si}, \mathrm{Na}, \mathrm{Sr}, \mathrm{Sn}, \mathrm{Ti}, \mathrm{U}, \mathrm{V}, \\
\mathrm{Zn}\end{array}$ & $0.5 \mathrm{~mL} 69 \% \mathrm{HNO}_{3}$ & $0.45 \mu \mathrm{m}$ membrane \\
\hline $\begin{array}{l}\text { Polyethylene } \\
\quad 250 \mathrm{~mL}\end{array}$ & Total alkalinity, $\mathrm{NO}_{2}$ and $\mathrm{NO}_{3}, \mathrm{Br}, \mathrm{Cl}, \mathrm{F}, \mathrm{SO}_{4}$ & NA & NA \\
\hline $\begin{array}{l}\text { Polyethylene } \\
\quad 250 \mathrm{~mL}\end{array}$ & Sulfur & $0.5 \mathrm{~mL} 5 \mathrm{~N} \mathrm{NaOH}$ & NA \\
\hline $\begin{array}{l}\text { Polyethylene } \\
\quad 250 \mathrm{~mL}\end{array}$ & Inorganic phosphorus & $0.5 \mathrm{~mL} 50 \% \mathrm{H}_{2} \mathrm{SO}_{4}$ & NA \\
\hline $\begin{array}{l}\text { Glass } \\
60 \mathrm{~mL}\end{array}$ & Ammoniacal nitrogen & $0.17 \mathrm{~mL}$ sulfuric acid & NA \\
\hline $\begin{array}{l}\text { Polyethylene } \\
\qquad 30 \mathrm{~mL}\end{array}$ & $\delta^{18} \mathrm{O}, \delta^{2} \mathrm{H}$ & NA & NA \\
\hline
\end{tabular}

Four precipitation gauges were installed within the Grenville Province and one precipitation gauge on the St. Lawrence Platform (Figure 2). Precipitation gauges are designed to collect both rain and snow for stable isotope analyses $\left(\delta^{2} \mathrm{H}\right.$ and $\left.\delta^{18} \mathrm{O}\right)$. The gauge precipitation was collected monthly over 12 months (1 July 2019 to 1 June 2020). We collected 20 groundwater samples in summer 2020 for $\delta^{2} \mathrm{H}$ and $\delta^{18} \mathrm{O}$ analyses. The $\delta^{2} \mathrm{H}$ and $\delta^{18} \mathrm{O}$ precipitation gauge data were used to trace the local meteoritic water line (LMWL). The $\delta^{2} \mathrm{H}$ vs. $\delta^{18} \mathrm{O}$ ratios were determined for each hydrogeological process and served to validate the impact of the geological environment on isotopic chemistry. Complete physicochemical data for the groundwater and precipitations are presented in Table 1. The location of groundwater samples collected for this study is shown in Figure 2. 


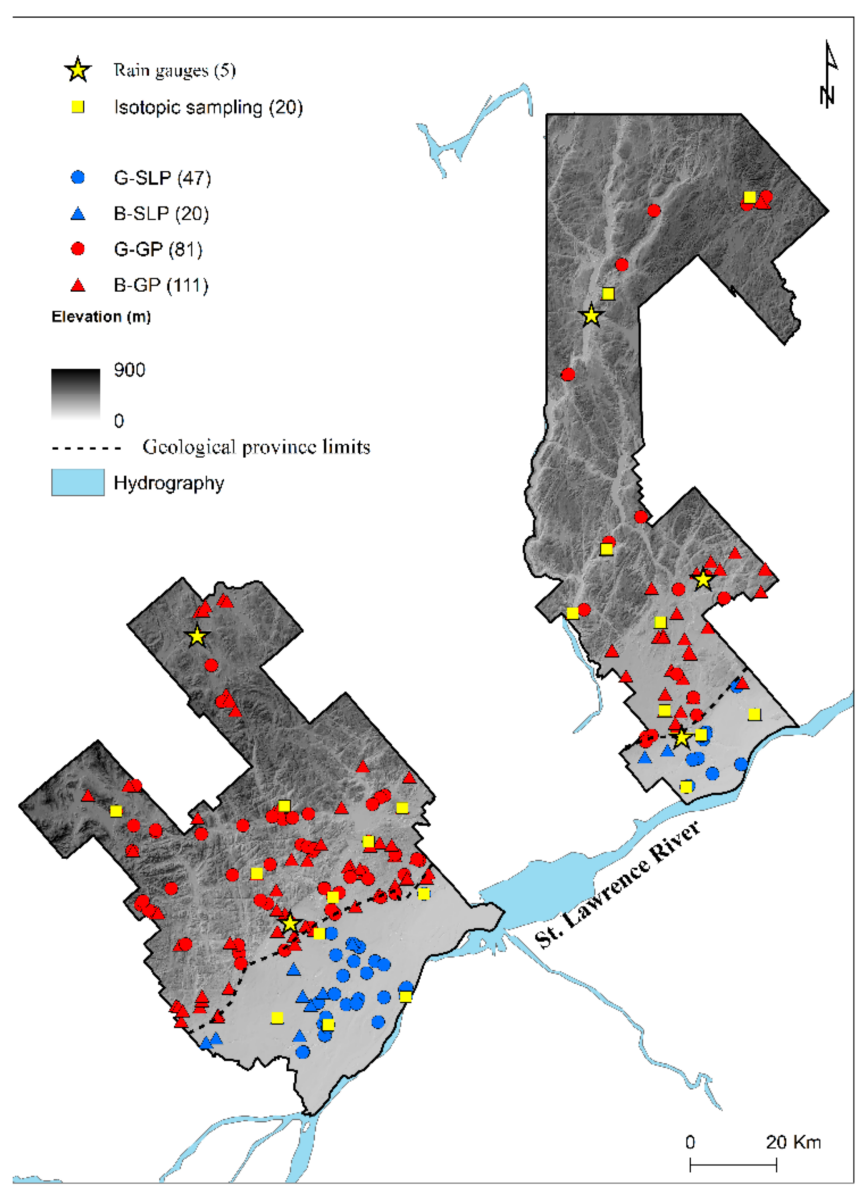

Figure 2. Location of the sampling sites classified according to their respective aquifer type and geological province. The St. Lawrence Platform has 67 sampling sites distributed in granular (G-SLP) and bedrock aquifers (B-SLP), whereas Grenville Province has 192 sampling sites distributed in granular (G-GP) and bedrock aquifers (B-GP). The five rainwater gauges are represented by yellow stars. The 20 sampling sites for isotopic analyses are represented by yellow squares.

\subsubsection{Preparation of the Regional Database}

The analytical results were validated by testing the ionic balance, for which a value of $\pm 10 \%$ is considered acceptable [28]. Accordingly, 25 samples were rejected because their ion balance values fell outside the recommended range. Consequently, 289 out of 314 collected samples were retained for statistical analysis. Then, the regional database was separated into four data sets according to geological province and aquifer type (granular deposits and bedrock aquifers within the Grenville Province and granular deposits and bedrock aquifers within the St. Lawrence Platform). The database included GPS coordinates and geochemical results in meq/L and $\mathrm{mmol} / \mathrm{L}$. Samples with an unknown aquifer were removed from the database. Therefore, a total of 259 samples were retained: 81 samples in granular deposit aquifers within the Grenville Province (G-GP), 111 samples in bedrock aquifers within the Grenville Province (B-GP), 47 samples in granular deposit aquifers of the St. Lawrence Platform (G-SLP), and 20 samples in bedrock aquifers within St. the Lawrence Platform (B-SLP). Figure 2 shows the sample locations of the 259 retained groundwater samples, the five rainwater gauges, and the 20 samples collected for stable isotope analyses.

\subsubsection{Univariate and Multivariate Statistical Analyses}

Univariate statistical analysis provided a summary of groundwater chemistry by describing the variables by parameters of central tendency (i.e., mean, mode, and median), 
position (i.e., quartiles), and dispersion (i.e., standard deviation and variance) [29]. To compare groundwater chemistry between the samples, we performed univariate statistics of the major and minor elements and the in situ parameters belonging to each data set.

Multivariate statistical methods commonly used in hydrogeology studies include the correlation matrix and principal component analysis (PCA) [30]. These statistics are based on a unique central value corresponding to the mean, median, and mode of the statistical distribution; therefore, data must respect a normal distribution. Minor and trace elements do not follow a normal distribution, however, because most samples have either very low or below-detection-limit concentrations [31]. In this study, only silica $\left(\mathrm{SiO}_{2}\right)$ followed a normal distribution. The other elements were log-transformed (Table 1). To ensure that each element in Table 1 had equal weight in the statistical analyses, we standardized the values by calculating their standard scores $\left(Z_{\mathrm{i}}\right)$ :

$$
\mathrm{Z}_{\mathrm{i}}=\frac{\mathrm{x}_{\mathrm{i}}-\overline{\mathrm{x}}}{\mathrm{s}}
$$

where $Z_{i}$ is the standard score of sample $i, x_{i}$ is the value of sample $i, \bar{x}$ is the mean, and $s$ is the standard deviation [32]. Elements used in multivariate statistical methods should have a detection ratio greater than $75 \%$ [14]. A total of 10 elements $\left(\mathrm{Ca}^{2+}, \mathrm{Mg}^{2+}, \mathrm{Na}^{+}, \mathrm{K}^{+}\right.$, $\mathrm{Ba}^{2+}, \mathrm{SiO}_{2}, \mathrm{Sr}^{2+}, \mathrm{HCO}_{3}{ }^{-}, \mathrm{Cl}^{-}, \mathrm{SO}_{4}{ }^{2-}$ ) respected the $75 \%$ threshold and were used in the multivariate analysis.

The correlation matrix is a bivariate statistical approach that is considered to be the initial step of multivariate analysis [33]. The significance of the correlation coefficient depends on the number of samples $(\mathrm{N})$ in each correlated set (Equation (2)). The correlation is significant when

$$
\frac{\left|\mathrm{r}_{\mathrm{xy}}\right|}{\frac{\sqrt{1-\mathrm{r}_{\mathrm{xy}}^{2}}}{\sqrt{\mathrm{N}-2}}}>\mathrm{s}(\alpha / 2)
$$

where $r_{x y}$ is the correlation coefficient, $N$ is the sample size, and $s(\alpha / 2)$ is the $t$-score for a significance level $\alpha$ [29].

Principal component analysis (PCA) extracts the main axes of variation within the data set, with the first component (first axis) corresponding to the dimension that explains the greatest amount of variance within the original data, the second component explaining the second-greatest amount of variance, and so forth [34]. According to the Kaiser criterion, components with an eigenvalue greater than one can be deemed reliable for use in interpreting the output [35]. Typically, the first two or three principal components sufficiently explain variation within a data set. The correlation matrix and PCA were applied to each data set using Rstudio software [36]. R-mode technique and Varimax normalized rotation were applied to maximize the variance of the first three principal axes [31]. Elements used in the correlation matrix and the PCA included major $\left(\mathrm{Ca}^{2+}, \mathrm{Mg}^{2+}, \mathrm{Na}^{+}, \mathrm{K}^{+}, \mathrm{HCO}_{3}{ }^{-}, \mathrm{Cl}^{-}\right.$, and $\left.\mathrm{SO}_{4}{ }^{2-}\right)$ and minor $\left(\mathrm{Ba}^{2+}, \mathrm{SiO}_{2}, \mathrm{Sr}^{2+}\right)$ elements.

\subsubsection{Saturation Index}

The saturation index (SI) compares the logarithm of the solubility product of the mineral $\left(\mathrm{K}_{\mathrm{sp}}\right)$ and ion activation product (IAP). The solubility is the amount of solute that can be dissolved, and the IAP involves the measured activities of the product [27]. The SI is expressed as:

$$
\mathrm{SI}=\log \frac{\mathrm{IAP}}{\mathrm{K}_{\mathrm{sp}}}
$$

At equilibrium, a SI value of 0 indicates that the solution is saturated with the mineral. For SI values less than 0 , there is a dissolution process reflected by undersaturated solutions, and for SI greater than 0 , there is a precipitation process reflected by an oversaturated solution with respect to the considered mineral [27]. The SI of the samples is calculated using PHREEQC [37]. 


\section{Results}

\subsection{Statistical Analysis}

Table 2 presents the median concentrations of major and minor elements and the in situ parameters. Groundwater type is defined by a combination of the major cation $\left(\mathrm{Ca}^{2+}\right.$, $\left.\mathrm{Mg}^{2+}, \mathrm{Na}^{+}, \mathrm{K}^{+}\right)$and anions $\left(\mathrm{HCO}_{3}{ }^{-}, \mathrm{Cl}^{-}\right.$, and $\left.\mathrm{SO}_{4}{ }^{2-}\right)$. In both the St. Lawrence Platform and Grenville Province, the groundwater type in descending order of dominance is $\mathrm{Ca}-$ $\mathrm{HCO}_{3}, \mathrm{Na}-\mathrm{HCO}_{3}$, and $\mathrm{Na}-\mathrm{Cl}$. For the granular aquifers, most groundwater samples in G-GP are $\mathrm{Ca}-\mathrm{HCO}_{3}$ (77\% of samples), whereas a slightly lower percentage of samples in the G-SLP (62\%) are $\mathrm{Ca}-\mathrm{HCO}_{3}$. G-GP samples show the lowest median concentrations for all major and minor elements, whereas the G-SLP has the most elevated median concentration of calcium.

Table 2. The median concentration of major and minor elements and in situ parameters. Major and minor elements with the highest median concentrations are in bold.

\begin{tabular}{|c|c|c|c|c|}
\hline & G-GP & B-GP & G-SLP & B-SLP \\
\hline & Grenville Province & Grenville Province & St. Lawrence Platform & St. Lawrence Platform \\
\hline Aquifer type & Granular & Bedrock & Granular & Bedrock \\
\hline$n$ & 81 & 111 & 47 & 20 \\
\hline \multirow{4}{*}{ Water type $(n)$} & $\mathrm{Ca}-\mathrm{HCO}_{3}(62)$ & $\mathrm{Ca}-\mathrm{HCO}_{3}(59)$ & $\mathrm{Ca}-\mathrm{HCO}_{3}(29)$ & $\mathrm{Ca}-\mathrm{HCO}_{3}(30)$ \\
\hline & $\mathrm{Na}-\mathrm{HCO}_{3}(10)$ & $\mathrm{Na}-\mathrm{HCO}_{3}(32)$ & $\mathrm{Na}-\mathrm{HCO}_{3}(8)$ & $\mathrm{Na}-\mathrm{HCO}_{3}(24)$ \\
\hline & $\mathrm{Ca}-\mathrm{Cl}(5) / \mathrm{Na}-\mathrm{Cl}(4)$ & $\mathrm{Ca}-\mathrm{Cl}(4) / \mathrm{Na}-\mathrm{Cl}(13)$ & $\mathrm{Ca}-\mathrm{Cl}(1) / \mathrm{Na}-\mathrm{Cl}(7)$ & $\mathrm{Ca}-\mathrm{Cl}(5) / \mathrm{Na}-\mathrm{Cl}(17)$ \\
\hline & $(\mathrm{Ca}-\mathrm{Na}) \mathrm{SO}_{4}(0)$ & $(\mathrm{Ca}-\mathrm{Na}) \mathrm{SO}_{4}(3)$ & $(\mathrm{Ca}-\mathrm{Na}) \mathrm{SO}_{4}(2)$ & $(\mathrm{Ca}-\mathrm{Na}) \mathrm{SO}_{4}(2)$ \\
\hline \multicolumn{5}{|c|}{ Major elements (mg/L) } \\
\hline Calcium & 14.00 & 20.00 & 28.00 & 19.00 \\
\hline Magnesium & 1.90 & 4.00 & 4.60 & 9.95 \\
\hline Potassium & 1.40 & 2.00 & 2.30 & 7.45 \\
\hline Sodium & 6.30 & 19.00 & 27.00 & 97.00 \\
\hline Chloride & 3.40 & 15.00 & 34.00 & 36.50 \\
\hline Sulfate & 7.80 & 16.00 & 11.00 & 8.00 \\
\hline Bicarbonate & 42.00 & 90.00 & 110.00 & 195.00 \\
\hline \multicolumn{5}{|c|}{ Minor elements (mg/L) } \\
\hline Barium & 0.014 & 0.021 & 0.042 & 0.230 \\
\hline Manganese & 0.008 & 0.010 & 0.004 & 0.016 \\
\hline Silicium & 5.60 & 5.90 & 5.40 & 7.20 \\
\hline Strontium & 0.083 & 0.22 & 0.17 & 0.52 \\
\hline Fluoride & 0.05 & 0.18 & 0.08 & 0.69 \\
\hline Ammonium & 0.02 & 0.05 & 0.04 & 0.59 \\
\hline Iron & 0.06 & 0.06 & 0.06 & 0.06 \\
\hline Sulfides & 0.02 & 0.02 & 0.02 & 0.04 \\
\hline \multicolumn{5}{|c|}{ In situ parameters } \\
\hline Dissolved $\mathrm{O}_{2}(\%)$ & 1.33 & 0.00 & 0.00 & 0.00 \\
\hline $\mathrm{pH}$ & 6.25 & 7.73 & 6.47 & 8.10 \\
\hline TDS (mg/L) & 32.00 & 103.00 & 161.00 & 204.00 \\
\hline
\end{tabular}

The bedrock aquifer samples for B-GP are mainly $\mathrm{Ca}-\mathrm{HCO}_{3}$ (53\% of samples) with some $\mathrm{Na}-\mathrm{HCO}_{3}(29 \%),(\mathrm{Na}-\mathrm{Ca})-\mathrm{Cl}(15 \%)$, and $(\mathrm{Na}-\mathrm{Ca}) \mathrm{SO}_{4}(3 \%)$. Bedrock groundwater samples from B-SLP are mainly $\mathrm{Ca}-\mathrm{HCO}_{3}(38 \%)$ and $\mathrm{Na}-\mathrm{HCO}_{3}(31 \%)$ with some (Na$\mathrm{Ca})-\mathrm{Cl}(28 \%)$ and $(\mathrm{Na}-\mathrm{Ca}) \mathrm{SO}_{4}(3 \%)$. The B-SLP samples are characterized by the highest median concentrations for all major and minor elements, calcium and sulfate excepted, as well as the highest levels of TDS and the most alkaline waters (median $\mathrm{pH}=8.1$ ). The median of TDS is under $300 \mathrm{mg} / \mathrm{L}$, which ranks as excellent according to the guidelines for Canadian drinking water quality [38]. 


\subsection{Correlation Matrix}

The correlation matrix of each data set is presented in Figure 3, and significance was evaluated using Equation (2). For the G-SLP groundwater data set, $\mathrm{Ca}^{2+}$ is significantly correlated (>0.38) with almost all other elements, except $\mathrm{SO}_{4}{ }^{2-}, \mathrm{SiO}_{2}$, and $\mathrm{Sr}^{2+}$, whereas within the G-GP groundwater data set, $\mathrm{Ca}^{2+}$ is not significantly correlated $(>0.29)$ with the other elements. $\mathrm{Ba}^{2+}$ in the granular aquifers of the St. Lawrence Platform (G-SLP) is strongly correlated to multiple elements.

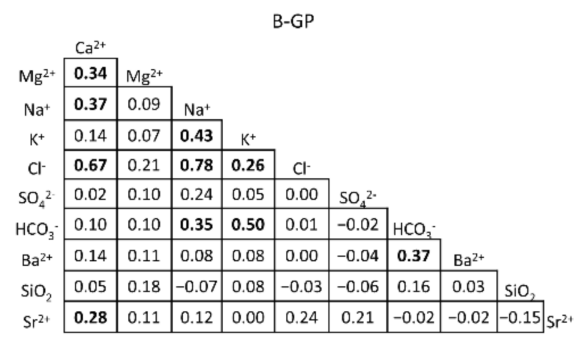

G-GP

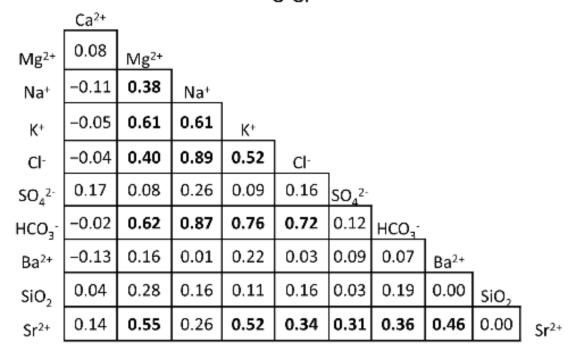

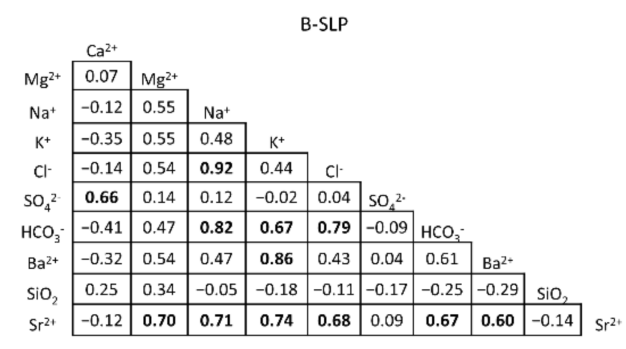

G-SLP

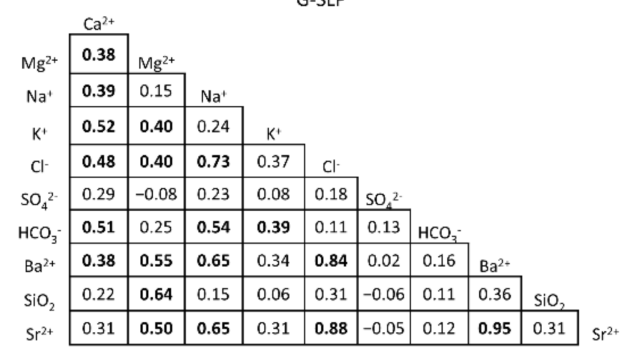

Figure 3. Correlation matrix of elements for the four data sets. Coefficient correlations in bold characters are considered as significant correlations according to Equation (2).

In the G-GP data set, $\mathrm{Mg}^{2+}, \mathrm{Na}^{+}, \mathrm{K}^{+}, \mathrm{Cl}^{-}, \mathrm{HCO}_{3}{ }^{-}$, and $\mathrm{Sr}^{2+}$ present multiple significant correlations with other elements. $\mathrm{Sr}^{2+}$ is often significantly correlated with other elements in the B-SLP, G-SLP, and G-GP data sets, although it has almost no correlation with other elements in the B-GP data set. We note significant correlations $(>0.25)$ for $\mathrm{Ca}^{2+}, \mathrm{Na}^{+}$, and $\mathrm{Cl}^{-}$in the B-GP data set, whereas the B-SLP data set shows a significant correlation $(>0.57)$ for $\mathrm{HCO}_{3}{ }^{-}$and $\mathrm{Sr}^{2+}$. The correlation matrix of groundwater chemistry illustrates differences between the four groups on the basis of the elements $\mathrm{Ca}^{2+}, \mathrm{Mg}^{2+}, \mathrm{Na}^{+}, \mathrm{HCO}_{3}{ }^{-}$, $\mathrm{Ba}^{2+}$, and $\mathrm{Sr}^{2+}$.

\subsection{Principal Component Analysis}

Ten components for each data set were extracted from the PCA. The first four components for G-GP and B-GP and the first three components for G-SLP and B-SLP had eigenvalues greater than 1 (Table 3). Loading values correspond to the importance of variance and vary from -1 to 1 . There is no literature on determining a minimum threshold for loading values to be meaningful. We considered loadings greater than 0.7 as significant (bold values in Table 3). 
Table 3. Principal component loadings and explained variance for the four groups separated by geological provinces and aquifer types. Bold values indicate a loading > 0.70; a threshold applied for establishing significance. GP, Grenville Province; SLP, St. Lawrence Platform; G: granular aquifer; B: bedrock aquifer.

\begin{tabular}{|c|c|c|c|c|c|c|c|c|c|c|c|c|c|c|}
\hline & \multicolumn{4}{|c|}{ B-GP } & \multicolumn{4}{|c|}{ G-GP } & \multicolumn{3}{|c|}{ B-SLP } & \multicolumn{3}{|c|}{ G-SLP } \\
\hline \multicolumn{15}{|c|}{ Components } \\
\hline Elements & $\mathrm{C} 1$ & $\mathrm{C} 2$ & $\mathrm{C} 3$ & $\mathrm{C} 4$ & C1 & C2 & $\mathrm{C} 3$ & $\mathrm{C} 4$ & $\mathrm{C} 1$ & $\mathrm{C} 2$ & $\mathrm{C} 3$ & $\mathrm{C} 1$ & $\mathrm{C} 2$ & $\mathrm{C} 3$ \\
\hline $\mathrm{Ca}^{2+}$ & 0.75 & -0.03 & 0.10 & 0.42 & -0.15 & -0.08 & 0.80 & 0.29 & -0.11 & -0.22 & 0.88 & 0.27 & 0.79 & 0.13 \\
\hline $\mathrm{Mg}^{2+}$ & 0.21 & 0.00 & 0.19 & 0.75 & 0.47 & 0.47 & 0.10 & 0.53 & 0.44 & 0.62 & 0.18 & 0.28 & 0.33 & 0.81 \\
\hline $\mathrm{Na}^{+}$ & 0.76 & 0.44 & 0.17 & -0.18 & 0.97 & -0.01 & 0.04 & -0.02 & 0.94 & 0.24 & 0.04 & 0.77 & 0.40 & -0.20 \\
\hline $\mathrm{K}^{+}$ & 0.31 & 0.73 & -0.05 & -0.13 & 0.70 & 0.44 & -0.04 & 0.21 & 0.27 & 0.91 & -0.4 & 0.18 & 0.67 & 0.21 \\
\hline $\mathrm{Cl}^{-}$ & 0.97 & 0.03 & 0.03 & 0.02 & 0.89 & 0.02 & 0.06 & 0.03 & 0.95 & 0.19 & -0.01 & 0.93 & 0.20 & 0.11 \\
\hline $\mathrm{SO}_{4}^{2-}$ & -0.06 & 0.13 & 0.80 & -0.05 & 0.22 & 0.16 & 0.70 & -0.31 & 0.05 & 0.09 & 0.93 & 0.13 & 0.41 & -0.49 \\
\hline $\mathrm{HCO}_{3}{ }^{-}$ & 0.02 & 0.87 & -0.03 & 0.15 & 0.90 & 0.16 & 0.01 & 0.22 & 0.79 & 0.43 & -0.23 & 0.04 & 0.82 & -0.01 \\
\hline $\mathrm{Ba}^{2+}$ & -0.11 & 0.50 & 0.07 & 0.39 & -0.06 & 0.84 & -0.14 & -0.10 & 0.24 & 0.89 & -0.08 & 0.90 & 0.14 & 0.30 \\
\hline $\mathrm{SiO}_{2}$ & -0.07 & 0.14 & -0.36 & 0.57 & 0.11 & -0.06 & 0.01 & 0.80 & -0.08 & -0.15 & -0.02 & 0.20 & 0.12 & 0.76 \\
\hline $\mathrm{Sr}^{2+}$ & 0.25 & -0.14 & 0.67 & 0.10 & 0.29 & 0.79 & 0.32 & 0.06 & 0.61 & 0.64 & 0.07 & 0.93 & 0.06 & 0.27 \\
\hline Eigenvalue & 2.29 & 1.78 & 1.30 & 1.30 & 3.43 & 1.80 & 1.27 & 1.21 & 3.12 & 2.77 & 1.76 & 3.37 & 2.25 & 1.74 \\
\hline $\begin{array}{c}\text { Explained } \\
\text { variance \% }\end{array}$ & 22.9 & 17.8 & 13.0 & 13.0 & 34.3 & 18.0 & 12.7 & 12.1 & 31.2 & 27.7 & 17.6 & 33.7 & 22.5 & 17.4 \\
\hline $\begin{array}{c}\text { Cumulative \% } \\
\text { of variance }\end{array}$ & 22.9 & 40.7 & 53.7 & 66.7 & 34.3 & 52.3 & 65.0 & 77.1 & 31.2 & 58.9 & 76.5 & 33.7 & 56.2 & 73.6 \\
\hline
\end{tabular}

For the Grenville Province data sets, the first four components of B-GP explain 22.9\%, $17.8 \%, 13.0 \%$, and $13.0 \%$, respectively, of the variance in the data set and a cumulative variance of $66.7 \%$. Component 1 is characterized by high positive loadings of $\mathrm{Ca}^{2+}, \mathrm{Na}^{+}$, and $\mathrm{Cl}^{-}$. Component 2 has significant positive loadings values for $\mathrm{K}^{+}$and $\mathrm{HCO}_{3}{ }^{-}$, whereas components 3 and 4 have significant positive loadings for $\mathrm{SO}_{4}{ }^{2-}$ and $\mathrm{Mg}^{2+}$, respectively. The first four components of G-GP explain 34.3\%, 18.0\%, 12.7\%, and $12.1 \%$ of the variance (77.1\% of the total variance) in the data set. Component 1 is characterized by significant positive loadings for $\mathrm{Na}^{+}, \mathrm{K}^{+}, \mathrm{Cl}^{-}$, and $\mathrm{HCO}_{3}{ }^{-}$, and component 2 is characterized by significant positive loadings for $\mathrm{Ba}^{2+}$ and $\mathrm{Sr}^{2+}$. Component 3 has a significant positive loading for $\mathrm{Ca}^{2+}$ and $\mathrm{SO}_{4}{ }^{2-}$, and component 4 has a significant positive loading for $\mathrm{SiO}_{2}$.

For the St. Lawrence Platform samples, the first three components of B-SLP explain, respectively, $31.2 \%, 27.7 \%$, and $17.6 \%$ of the variance $(76.5 \%$ in total) in the data set. Component 1 is characterized by significant positive loadings for $\mathrm{Na}^{+}, \mathrm{Cl}^{-}$, and $\mathrm{HCO}_{3}{ }^{-}$, whereas component 2 has significant positive loadings for $\mathrm{K}^{+}$and $\mathrm{Ba}^{2+}$, and component 3 has significant positive loading values of $\mathrm{Ca}^{2+}$ and $\mathrm{SO}_{4}{ }^{2-}$. The first three components of G-SLP explain $33.7 \%, 22.5 \%$, and $17.4 \%$ of the variance in the data set $(73.6 \%$ in total). Component 1 is characterized by significant positive loadings for $\mathrm{Na}^{+}, \mathrm{Cl}^{-}, \mathrm{Ba}^{2+}$, and $\mathrm{Sr}^{2+}$. Component 2 has significant positive loadings for $\mathrm{Ca}^{2+}$ and $\mathrm{HCO}_{3}{ }^{-}$, whereas component 3 has significant positive loadings for $\mathrm{Mg}^{+}$and $\mathrm{SiO}_{2}$.

Overall, $\mathrm{Na}^{+}$and $\mathrm{Cl}^{-}$concentrations appear as the key elements for explaining the variance within the data sets because these elements have high positive loadings on the first component for all the four aquifer-bedrock groups. In contrast, $\mathrm{Mg}^{2+}$ and $\mathrm{SiO}_{2}$ explain very little variance within the four data sets.

\section{Interpretation and Discussion}

\subsection{Hydrogeological Processes Affecting Groundwater Chemistry}

The postglacial Champlain Sea incursion onto the St. Lawrence Platform and Grenville Province at around ca. 11,000 to 13,000 year BP deposited a thick layer of marine clays [12,39] to create new hydrogeochemical conditions within the regional aquifers. Groundwater in some confined aquifers is characterized by higher concentrations of $\mathrm{Na}^{+}$and $\mathrm{Cl}^{-}$owing to stagnant saline water and marine clay pore waters [12,13]. On a $\mathrm{Cl}^{-}$vs. $\mathrm{Br}^{-}$plot with seawater [40] and Champlain Sea [25] samples (Figure 4), a number of samples from both the Grenville Province $(n=25)$ and St. Lawrence Platform $(n=11)$ geological provinces, plot along the seawater mixing line. 


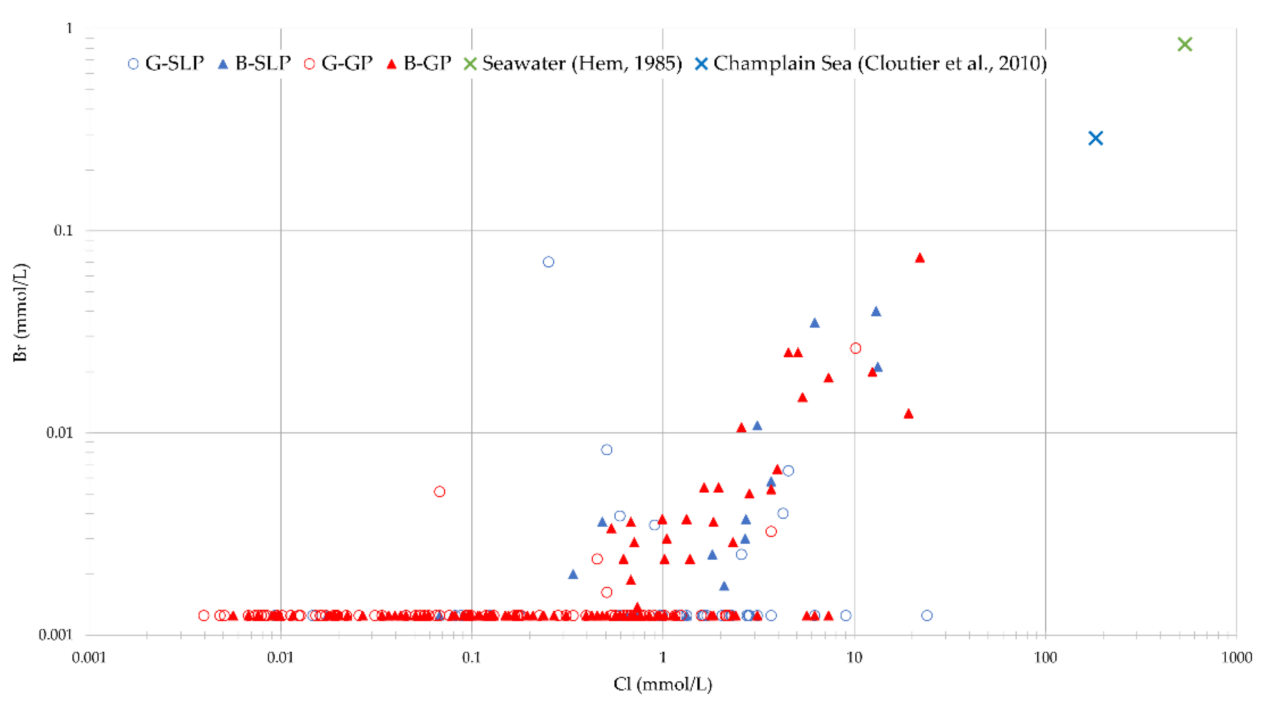

Figure 4. Binary diagram plotting $\mathrm{Br}^{-}$vs. $\mathrm{Cl}^{-}$vs. in mmol/L. Samples are represented according to their geological province and their type of aquifer. The green cross $X$ represents the composition of average seawater [40]. The blue ' $x$ ' represents the composition of the Champlain Sea [25].

These samples along the seawater mixing line suggest a process of freshening the Champlain Sea groundwater. The freshwater samples are often dominated by $\mathrm{Ca}^{2+}$ and $\mathrm{HCO}_{3}{ }^{-}$ions, resulting from carbonate dissolution or/and silicate weathering, whereas the trapped seawater is dominated by $\mathrm{Na}^{+}$and $\mathrm{Cl}^{-}$. During this mixing, $\mathrm{Na}^{+}$is desorbed, resulting in an exchange of $\mathrm{Ca}^{2+}$ with $\mathrm{Na}^{+}[13,27]$ following Equation (4):

$$
\frac{1}{2} \mathrm{Ca}^{2+}+\mathrm{Na}-\mathrm{X} \leftrightarrow \frac{1}{2} \mathrm{Ca}-\mathrm{X}_{2}+\mathrm{Na}^{+}
$$

Cloutier et al. (2004) [12] demonstrated that the Champlain Sea incursion caused groundwater salinization through various stages of cation exchange; these exchanges produced $\mathrm{Na}-\mathrm{HCO}_{3}$ and $\mathrm{Na}-\mathrm{Cl}$ groundwaters.

Carbonate and silicate dissolution in freshwater constitutes one of the main chemical processes in groundwater recharge areas [25]. The equilibrium equations for calcite (Equation (5)) and anorthite (Equation (6)) weathering by carbonic acid are also presented visually in a $\mathrm{Ca}^{2+}$ vs. $\mathrm{HCO}_{3}{ }^{-}$plot (Figure 5a), and the equilibrium lines for the dissolution of dolomite based on Equation (7) are plotted in an $\mathrm{Mg}^{2+} \mathrm{vs} \mathrm{Ca}^{2+}$ plot (Figure 5b) [40,41].

$$
\begin{gathered}
\text { Calcite : } \mathrm{CaCO}_{3}+\mathrm{H}_{2} \mathrm{O}+\mathrm{CO}_{2} \leftrightarrow \mathrm{Ca}^{2+}+2 \mathrm{HCO}_{3}^{-}, \\
\text {Anorthite : } \mathrm{CaAl} \mathrm{Si}_{2} \mathrm{O}_{8}+3 \mathrm{H}_{2} \mathrm{O}+2 \mathrm{CO}_{2} \leftrightarrow \mathrm{Ca}^{2+}+2 \mathrm{HCO}_{3}^{-}+\mathrm{Al}_{2} \mathrm{Si}_{2} \mathrm{O}_{5}(\mathrm{OH})_{4}, \\
\text { Dolomite : } \mathrm{CaMg}\left(\mathrm{CO}_{3}\right)_{2}+2 \mathrm{H}_{2} \mathrm{O}+2 \mathrm{CO}_{2} \leftrightarrow \mathrm{Ca}^{2+}+\mathrm{Mg}^{2+}+4 \mathrm{HCO}_{3}^{-} .
\end{gathered}
$$



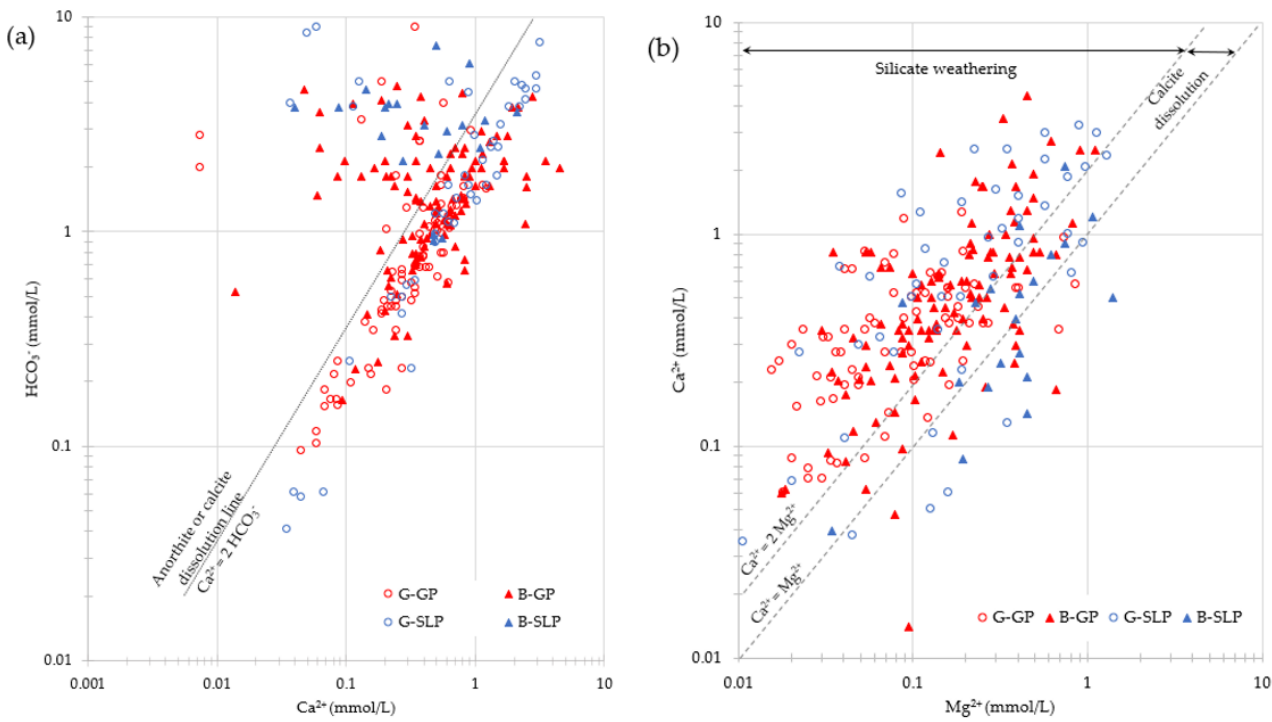

Figure 5. Plots of (a) $\mathrm{Ca}^{2+}$ vs. $\mathrm{HCO}_{3}{ }^{-}$concentrations and (b) $\mathrm{Mg}^{2+}$ vs. $\mathrm{Ca}^{2+}$ concentrations The groundwater samples are identified according to geological province and aquifer type. The equilibrium equations for calcite and anorthite weathering by carbonic acid are plotted in Figures $5 \mathrm{a}$ and $5 b$, and the equilibrium line for the dissolution of dolomite is plotted in Figure $5 b$. GP, Grenville Province; SLP, St. Lawrence Platform; G: granular aquifer; B: bedrock aquifer.

In Figure 5a, most groundwater samples plot along the equilibrium line of calcite or anorthite dissolution, except for those from the B-SLP data set. Carbonate dissolution depends on the dissolution of carbonic acid (Equations (5) and (6)). Some B-GP and B-SLP groundwater samples fall above the calcite or anorthite equilibrium line indicating that carbonate dissolution is not the dominant process (Figure 5a). The $\mathrm{Ca}^{2+}$ concentrations of the Grenville Province samples originate mainly from silicate weathering (Figure 5b), corresponding to the presence of silicate-rich rocks and sediments. The $\mathrm{Ca}^{2+}$ concentrations of the St. Lawrence Platform samples originate from silicate weathering and calcite dissolution (Figure 5b) owing to the presence of silicate-rich sediments and calcium-rich bedrock composed of sandstone conglomerate, dolomite, limestone, and shale [19-24].

The rainwater generally has a short residence time and is undersaturated in calcite [27]. Our samples follow a linear relationship between dolomite and calcite SI (Figure 6), for which equilibrium is reached at a calcite SI and dolomite SI equal to zero with an uncertainty of \pm 0.5 units for dolomite and \pm 0.1 units for calcite [42,43]. Samples of all four data sets show an evolution from an undersaturation to an oversaturation state and confirm that dissolution and precipitation processes occur for dolomite and calcite. Generally, groundwater in the bedrock aquifers approaches the equilibrium state of calcite and dolomite, whereas the groundwater in granular aquifers is undersaturated in calcite and dolomite. The dissolution of calcite and dolomite is active in the sedimentary rock aquifer systems, and, in our study, it is mainly the result of a water-rock interaction with the dolostone and limestone formations of the St. Lawrence Platform [23,24]. 


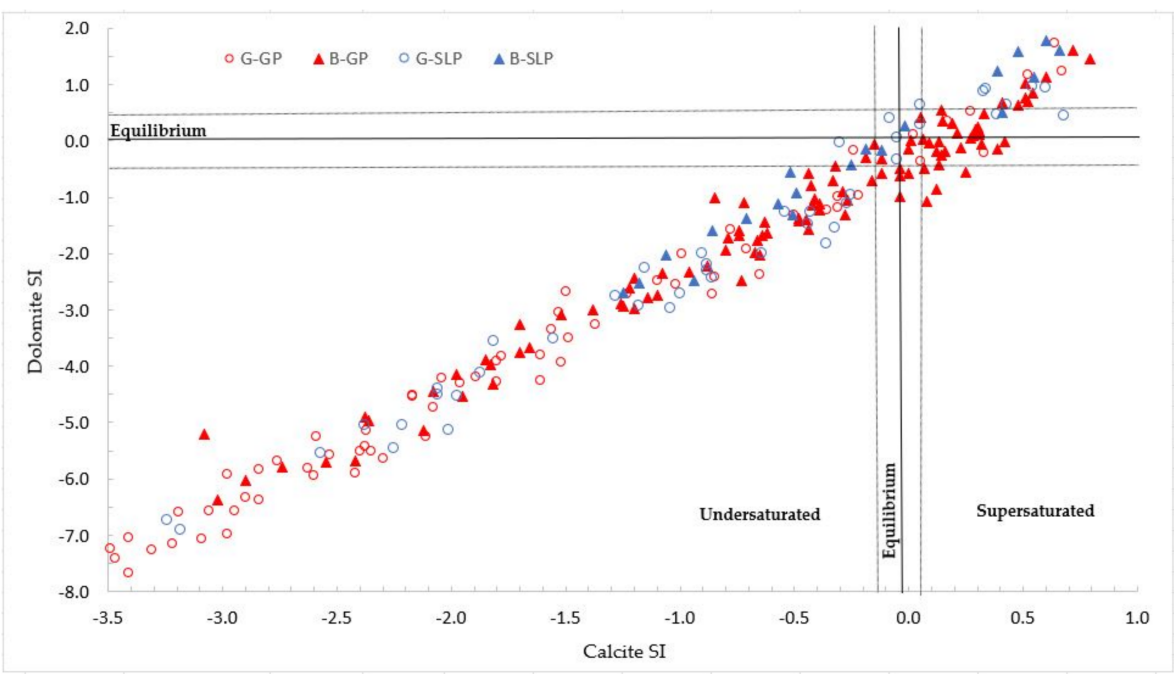

Figure 6. The calcite saturation index (SI) vs. dolomite SI. GP, Grenville Province; SLP, St. Lawrence Platform; G: granular aquifer; B: bedrock aquifer.

\subsection{Chemical Evolution of Groundwater}

Groundwater chemical evolution in the Grenville Province and St. Lawrence Platform can be discerned using $\mathrm{Ca}^{2+}$ vs. $\mathrm{Na}^{+} \log -\log$ plots and Piper diagrams [14]. The salinization of groundwater because of the dissolution of salt minerals or mixing with seawater causes groundwater to evolve along a salinization path [13]. The salinization pathways observed for our samples in the Piper diagram (Figure 7) and $\mathrm{Ca}^{2+}$ vs. $\mathrm{Na}^{+} \log -\log$ plot (Figure 8) indicate (i) a gradual evolution from $\mathrm{Ca}-\mathrm{HCO}_{3}$ groundwater toward a more concentrated $\mathrm{Na}-\mathrm{HCO}_{3}$ type and a further evolution toward a $\mathrm{Na}-\mathrm{Cl}$ groundwater via freshening and/or mixing with seawater, and (ii) evolution of $\mathrm{Ca}-\mathrm{HCO}_{3}$ groundwater toward a $\mathrm{Ca}-\mathrm{Cl}$ type through intrusion. Most samples from granular aquifers are freshwater in the Piper diagrams (Figure 7), corresponding to $\mathrm{Ca}-\mathrm{HCO}_{3}$ clusters in the $\mathrm{Ca}^{2+}$ vs. $\mathrm{Na}^{+} \log -\log$ plots (Figure 8). The latter plots suggest that the groundwater samples belonging to the four groups were subjected to a $\mathrm{Ca}^{2+} / \mathrm{Na}^{+}$cation exchange process, whereas the Piper diagrams suggest that cation exchange evolved through freshening, intrusion, and mixing with the fossil water of the Champlain Sea.
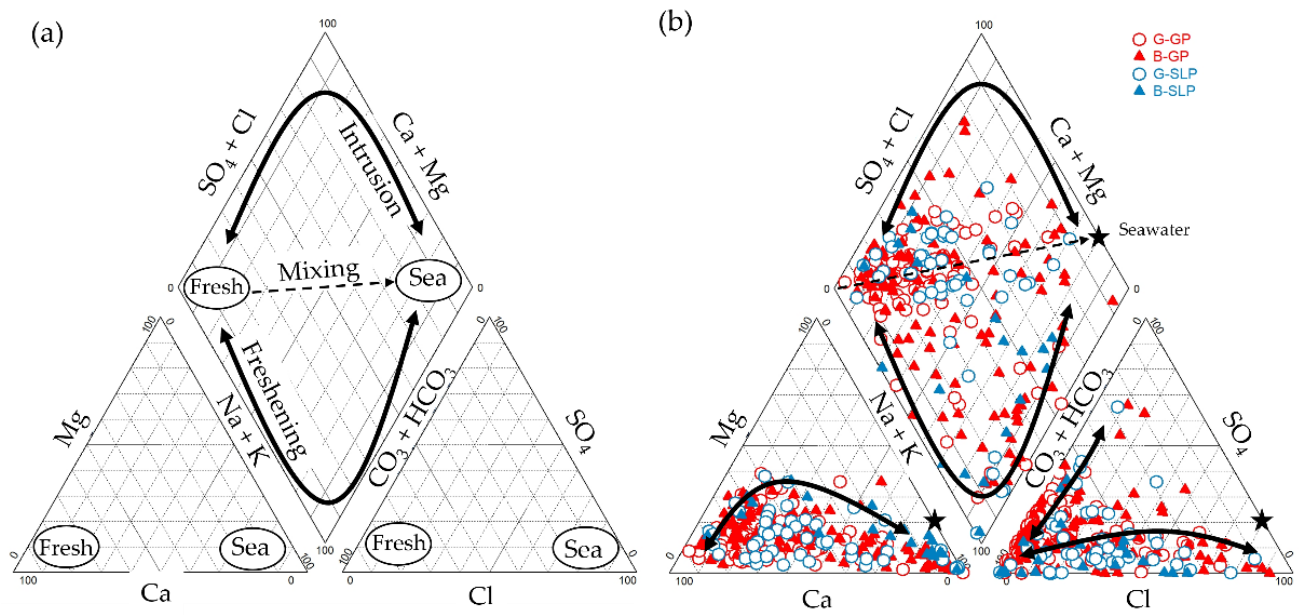

Figure 7. Piper diagrams show (a) the average composition of freshwater and seawater in relation to freshening, mixing, and intrusion $[27,44]$. The arrows correspond to the salinization paths presenting the $\mathrm{Ca}-\mathrm{HCO}_{3}$ type in recharge areas toward $\mathrm{Na}-\mathrm{HCO}_{3}$ and $\mathrm{Na}-\mathrm{Cl}$ waters. The dashed line represents the evolution of freshwater toward seawater via a mixing process [27]. (b) Piper diagram with our groundwater samples reported according to their respective aquifer/geological province data sets. GP, Grenville Province; SLP, St. Lawrence Platform; G: granular aquifer; B: bedrock aquifer. 

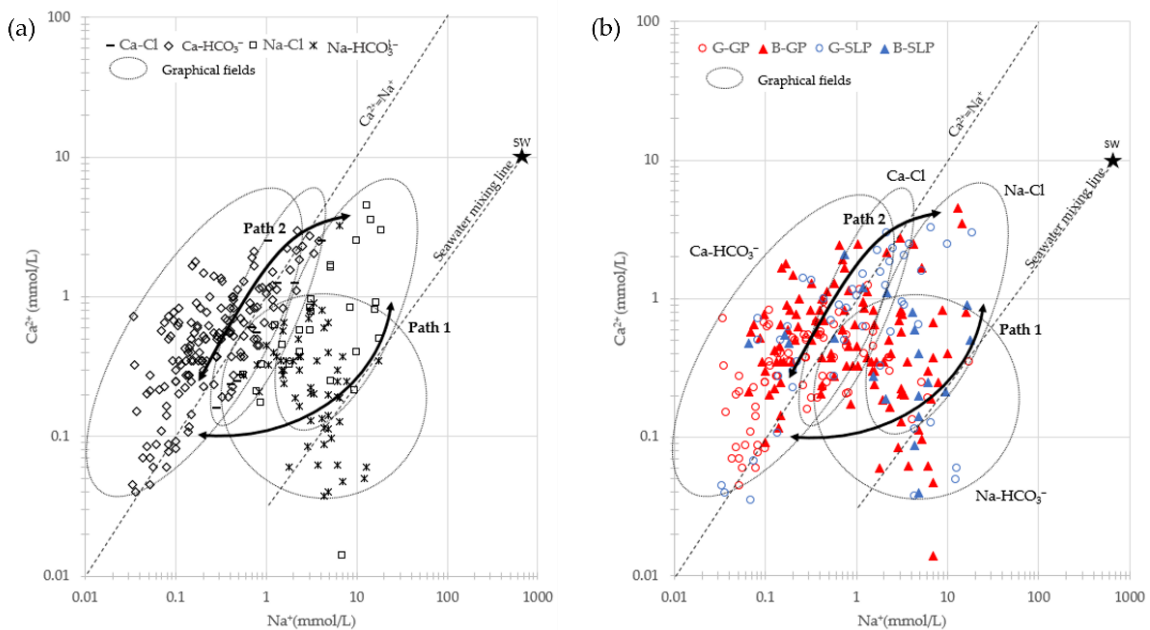

Figure 8. Plots of $\mathrm{Na}^{+}$vs. $\mathrm{Ca}^{2+}$ concentrations in mmol/l. (a) The samples are grouped by ellipses representing the dominant facies (graphical fields); (b) the samples are grouped by ellipses representing their respective geological province-aquifer type data sets. The seawater mixing line and seawater concentration (SW) were defined using seawater ratios from Goldberg et al. [45]. GP, Grenville Province; SLP, St. Lawrence Platform; G: granular aquifer; B: bedrock aquifer.

The chemical evolution of groundwater can also be interpreted using Gibbs's diagram (1970) [46]. This diagram of TDS (mg/L) versus the $\mathrm{Cl}^{-}: \mathrm{Cl}^{-}+\mathrm{HCO}_{3}{ }^{-}(\mathrm{mmol} / \mathrm{L})$ is divided into three poles (rainfall, rock dominance, and seawater) and three hydrogeochemical mechanisms (mineralization, freshening, and mixing). Water-rock interactions and freshening appear to be the main processes affecting the $\mathrm{Ca}^{2+} / \mathrm{Na}^{+}$cationic exchange within both geological provinces (Figure 9). Water-rock interactions occur mainly for bedrock aquifers, whereas freshening occurs in both aquifers. Freshening occurs when freshwater recharge replaces saline groundwater originating from a seawater intrusion [47].

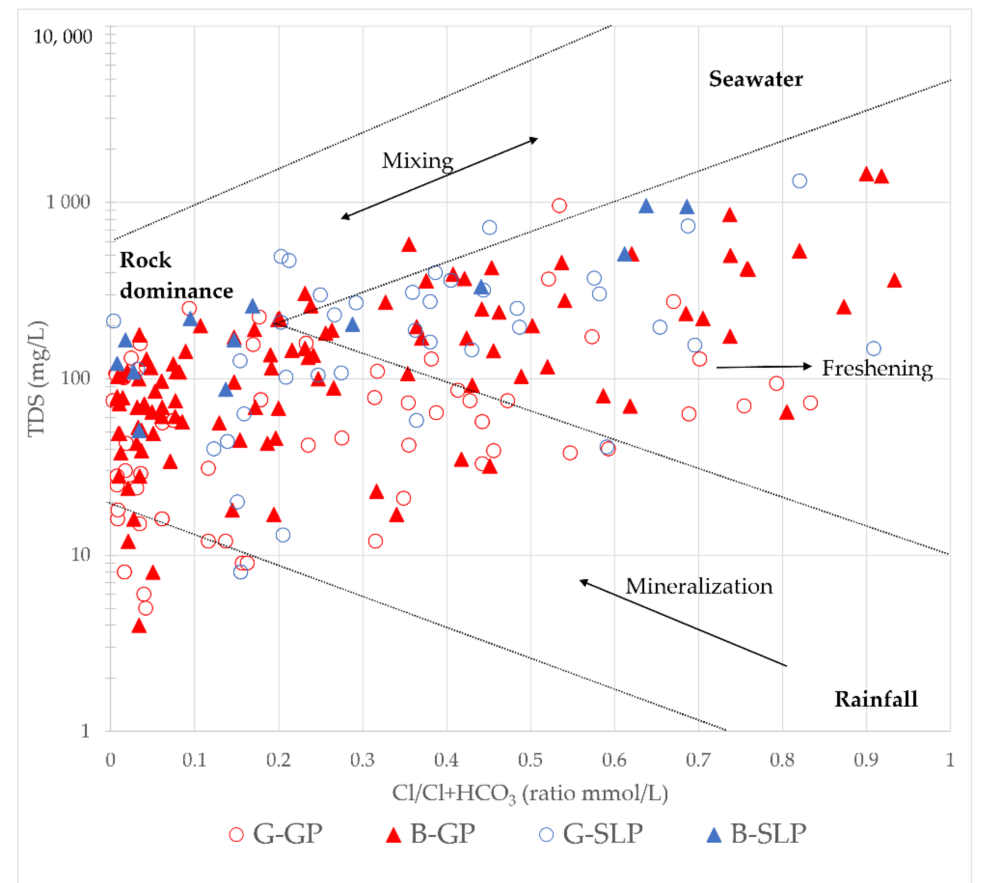

Figure 9. Gibbs's diagram of the TDS concentration vs. the $\mathrm{Cl} / \mathrm{Cl}+\mathrm{HCO}_{3}$ ratio to determine the main process influencing groundwater evolution. Samples are classified according to their geological province and aquifer type. GP, Grenville Province; SLP, St. Lawrence Platform; G: granular aquifer; B: bedrock aquifer. 


\subsection{Regional Hydrogeochemical Conceptual Model}

We can summarize the regional hydrogeochemical conceptual model of groundwater in the Grenville Province and St. Lawrence platform in four stages (Figure 10). We can then compare our model with the southeastern part of the Mauricie region of Quebec, a region that was the subject of a previous hydrogeochemical characterization by Lacasse [10]. The southeastern part of the Mauricie region is located between the Lanaudière and Eastern Mauricie region and is also located at the boundary of the Grenville and St. Lawrence Platform geological provinces.

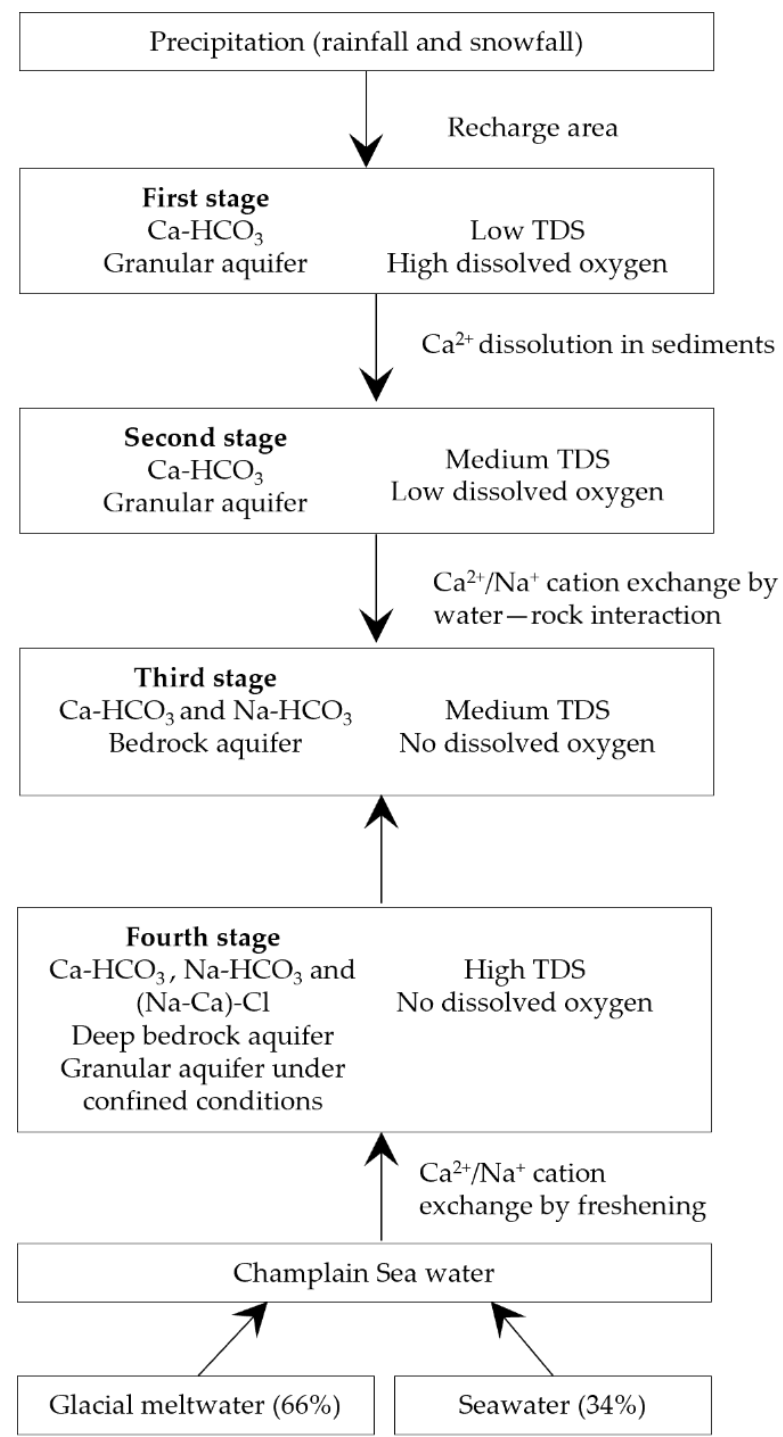

Figure 10. A regional hydrogeochemical conceptual model of groundwater evolution and groundwater characteristics, including water type, aquifer type, TDS, dissolved oxygen, and the dominant geochemical processes.

The first stage of the conceptual model is the precipitation in the form of rainfall and snowfall. This precipitation infiltrates the recharge areas and initiates the dissolution reactions with the sediments. The recharging water, corresponding to $\mathrm{Ca}-\mathrm{HCO}_{3}$ groundwater, has highly dissolved oxygen and low TDS.

The second stage is the carbonate and silicate dissolution in freshwater, which constitutes one of the early chemical processes affecting regional groundwater recharge areas [25]. Acidic groundwater more easily dissolves calcite minerals, thereby increasing calcium concentrations in groundwater [27]. Carbonate dissolution is a major factor within the St. 
Lawrence Platform, with bedrock composed of calcium-rich sedimentary rocks. Silicate dissolution is effective in both the St. Lawrence Platform and Grenville Province, each with silicate-rich sediments. As for the southeastern part of the Mauricie region, the evolution of the $\mathrm{Ca}-\mathrm{HCO}_{3}$ water type toward $\mathrm{Na}-\mathrm{HCO}_{3}$ groundwater owing to cationic exchange is the most important process [10].

The third stage represents a $\mathrm{Ca}^{2+} / \mathrm{Na}^{+}$cation exchange during the interaction between the bedrock and groundwater. The process of silicate dissolution in bedrock aquifers with carbonic acid transforms $\mathrm{Ca}-\mathrm{HCO}_{3}$ groundwater into $\mathrm{Na}-\mathrm{HCO}_{3}$ waters. The final stage is the $\mathrm{Ca}^{2+} / \mathrm{Na}^{+}$cation exchange through freshening in bedrock and granular aquifers. Our data sets include some samples obtained from deep bedrock aquifers (60-114 m depth) and others from confined conditions under thick layers of clay, which are evolving from $\mathrm{Ca}-$ $\mathrm{HCO}_{3}$ to $\mathrm{Na}-\mathrm{HCO}_{3}$ and finally to $\mathrm{Na}-\mathrm{Cl}$, as shown in Figure 9. The mixing of freshwater with seawater leads to the absorption of $\mathrm{Ca}^{2+}$ and $\mathrm{Mg}^{2+}$ by ion exchangers-usually clayand the release of $\mathrm{Na}^{+}$into the groundwater [27]. These observations suggest that fossil water of the Champlain Sea remains present within both geological provinces and, through $\mathrm{Ca}^{2+}$ and $\mathrm{Na}^{+}$cation exchange, is the primary factor influencing groundwater evolution.

\subsection{Trace Chemicals and Groundwater Quality}

Thirty-three percent of sampled wells in the Lanaudière and Eastern Mauricie regions exceeded the Canadian drinking water aesthetic threshold for manganese $(0.02 \mathrm{mg} / \mathrm{l})$, and $10 \%$ of the sampled wells exceeded the maximum acceptable level $(0.12 \mathrm{mg} / \mathrm{L})$ for $\mathrm{Mn}$. High levels of Mn represent an aesthetic concern for drinking water because Mn discolors water and can stain laundry [48]. Manganese is sensitive to variation in redox conditions [27]. High Mn groundwater samples from both the Grenville Province $(n=20)$ and St. Lawrence Platform $(n=12)$ originated from granular aquifers. Three hypotheses could explain the spatial variation in Mn concentrations within granular aquifers. First, the presence of organic matter decreases oxygen and nitrate concentrations in groundwater. This scenario creates a reducing environment that accelerates the solubilization of Mn [49]. Second, Mn concentrations increase in groundwater with the dissolution of Fe-oxyhydroxides under reducing conditions [50]. Third, groundwater is affected by the leakage of domestic sewage, characterized by low Eh and dissolved oxygen levels, in urban environments [49]. The Mn-rich groundwater samples recovered from wells on granular aquifers in the St. Lawrence Platform and groundwater samples collected from the transition zone between lowlands and highlands in Grenville Province were from sites proximal to (40-700 m) natural reducing environments, including bogs, fens, and backwater environments. These groundwater samples also have low dissolved oxygen and low Eh values ( -457 to $237 \mathrm{mV}$ ). These environmental conditions suggest that the Mn contamination in granular aquifers reflects the introduction of organic matter to produce a natural reducing environment.

For the St. Lawrence Platform, 19\% of the sampled wells exceeded the Canadian drinking water aesthetic threshold for sulfur $(0.05 \mathrm{mg} / \mathrm{L})$, expressed as hydrogen sulfide [48]. Sulfide in groundwater is produced through a variety of natural sources, including the dissolution of soluble $\mathrm{SO}_{4}{ }^{2-}$ and $\mathrm{S}^{2-}$ minerals in sedimentary rocks. Sulfide can also occur naturally in coal, natural gas, and oil [51,52]. Furthermore, sulfide can originate from human activities, such as residential waste or atmospheric, industrial, and agricultural contamination [51]. The sampled wells with an excessive concentration in sulfide reach mainly deep, bedrock aquifers (15-107 $\mathrm{m}$ ), characterized by no dissolved oxygen, basic $\mathrm{pH}$ (7.34-8.89), and low Eh rates $(-368$ to $-225 \mathrm{mV})$. These physicochemical properties suggest that the sulfide contamination could be (i) generated from the anaerobic degradation of organic matter-containing sulfide in the sedimentary rocks of St. Lawrence Platform or (ii) introduced from natural gas; its presence within the St. Lawrence Platform was well documented by Pinet et al., Castonguay et al., Moritz et al., and Ladevèze et al. [53-56].

Although fluoride is added to the drinking water in many municipal water suppliesto prevent tooth decay where fluoride is absent-high fluoride concentrations can lead to dental fluorosis and skeleton fluorosis [48]. Four percent of the sampled wells within the 
Grenville Province exceeded the Canadian drinking water and the World Health Organization threshold of $1.5 \mathrm{mg} / 1$ set to avoid fluorosis [48]. Fluoride concentration has primarily a geogenic origin for which the potential sources include fluorite, fluorapatite, amphibole, micas, and biotite $[13,57]$. Fluorite $\left(\mathrm{CaF}_{2}\right)$ is the most common mineral containing fluorine. Fluoride concentrations increase when fluorite precipitation leads to calcium-poor groundwater or when $\mathrm{Ca}^{2+}$ is exchanged with $\mathrm{Na}^{+}$leading to a decreased $\mathrm{Ca}^{2+}$ content in groundwater $[14,58]$. Fluoride concentrations above the $1.5 \mathrm{mg} / \mathrm{L}$ thresholds are mainly associated with wells in the Eastern Mauricie region within the Grenville Province, in locations characterized by a lack of dissolved oxygen, basic $\mathrm{pH}$ (7.4-8.8), deep bedrock aquifers (60-170 m depth), and $\mathrm{Na}-\mathrm{HCO}_{3}$ and $\mathrm{Na}-\mathrm{Cl}$ water types. The concentration of fluoride remains constant in seawater at approximately $1.3 \mathrm{mg} / \mathrm{L}$ [58]. Given that the fluoride concentrations of the F-impacted wells range from 1.7 to $7.3 \mathrm{mg} / \mathrm{L}$, seawater cannot be the sole source of fluoride in these samples. Fluorine can substitute with hydroxyl ions in amphibole, biotite, chlorite, and tourmaline because of the similarity between their ionic radius [59]. As the geology at the F-impacted sampling wells is tonalitic and trondhjemitic gneiss containing quartz, plagioclase, biotite, and amphibole, it is quite likely that these rocks are the main source of fluoride in groundwater [19-22].

The sampled wells with an excessive concentration in sulfide and fluoride are reported on $\mathrm{Ca}^{2+}$ vs. $\mathrm{Na}^{+} \log -\log$ plots (Figure 11). These samples evolve along the salinization path, suggesting that the groundwater samples belonging to the excessive concentration in sulfide and fluoride were subjected to a $\mathrm{Ca}^{2+} / \mathrm{Na}^{+}$cation exchange process.

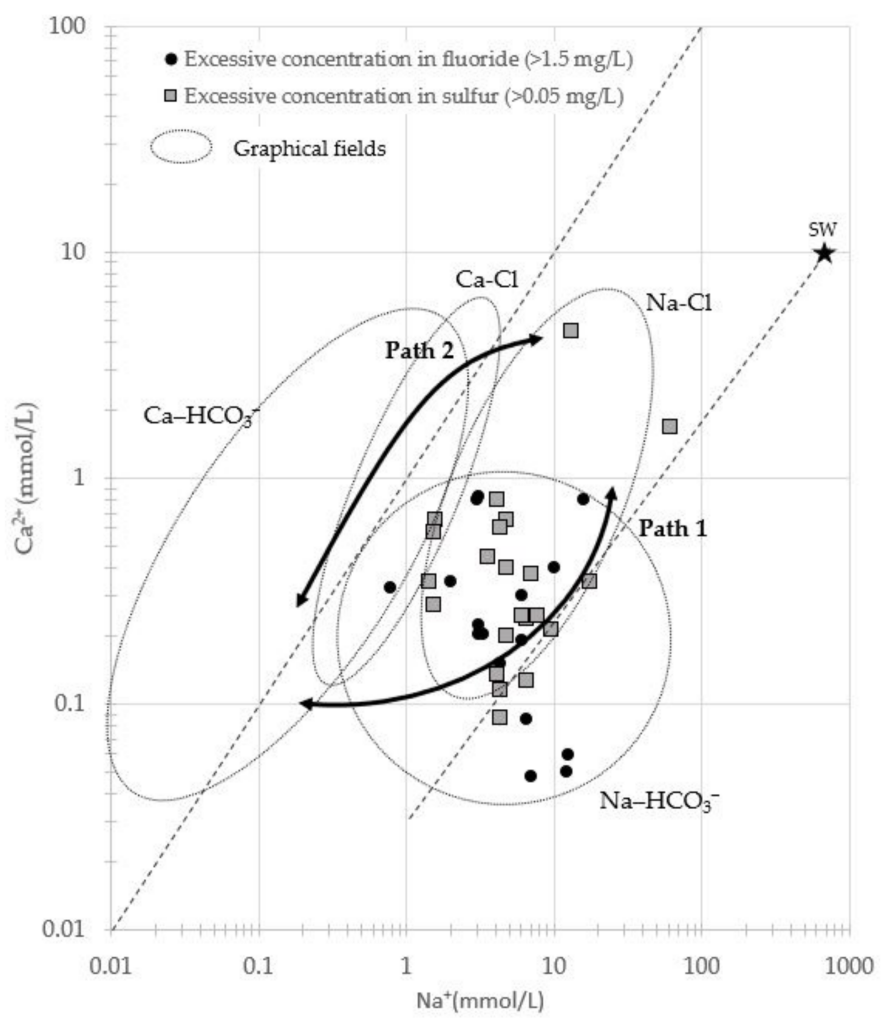

Figure 11. Plot of $\mathrm{Na}^{+}$vs. $\mathrm{Ca}^{2+}$ concentrations in $\mathrm{mmol} / \mathrm{l}$. Samples with an excessive concentration in sulfide and fluoride evolve along the salinization path 1 . The seawater mixing line and seawater concentration (SW) were defined using seawater ratios from Goldberg et al. [45].

Manganese, sulfur, and fluoride represent minor elements that could improve our understanding of the chemical composition of the aquifer, as these elements are spatially correlated to the specific geological context within the larger geological provinces, i.e., sulfur in the St. Lawrence Platform and fluoride in the Grenville Province. 


\subsection{Isotopic Validation}

We relied on the isotopic data of regional precipitation to establish the local meteoritic water line (LMWL) on a $\delta^{2} \mathrm{H}$ vs. $\delta^{18} \mathrm{O}$ binary diagram (Figure 12$)$. The collected precipitation samples plot along the global meteoritic water line (GMWL), indicating no significant isotopic fractioning by evaporation. The global isotopic variation in rainwater is affected by kinetic fractionation during condensation and evapotranspiration [27]; rainfall is mainly isotopically depleted due to (i) altitude and (ii) the distance from the coast [60]. Two outlier points marked by low $\delta^{2} \mathrm{H} / \delta^{18} \mathrm{O}$ ratios represent snowfall samples collected at high altitudes in St.-Michel-des-Saints (421 m) and La Tuque (167 m), Quebec.

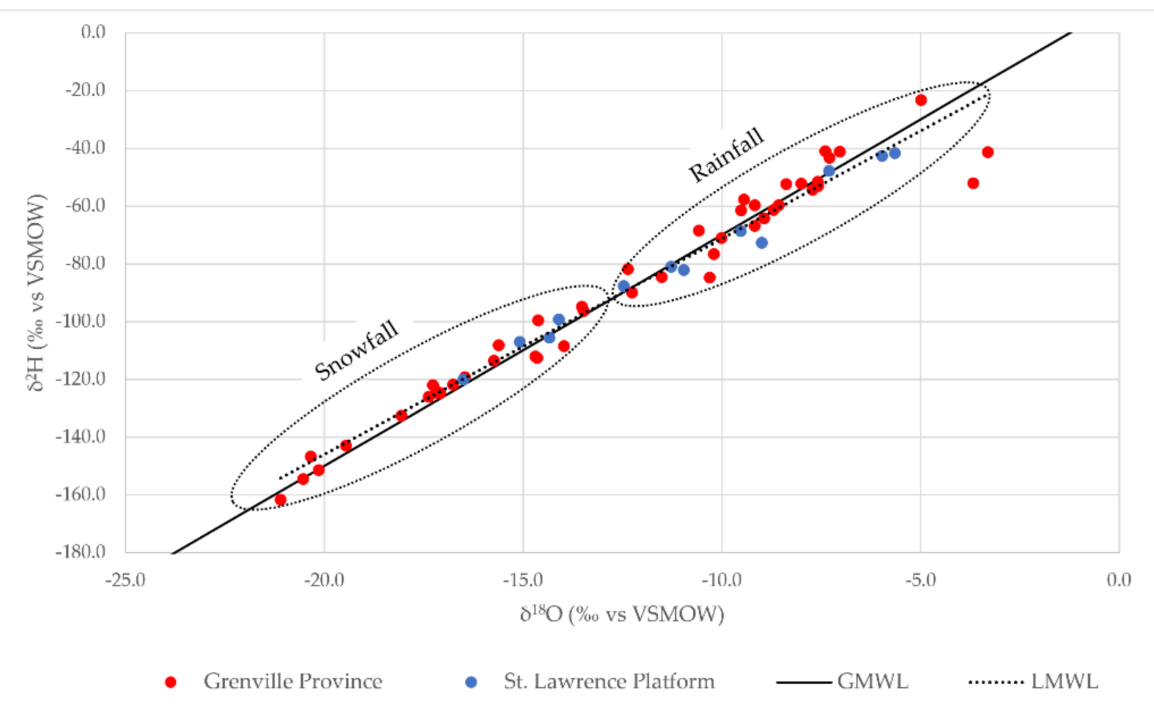

Figure 12. Binary diagram of $\delta^{2} \mathrm{H}$ vs. $\delta^{18} \mathrm{O}$ of precipitation data collected at the five precipitation gauges within the Grenville Province and St. Lawrence Platform. GMWL, global meteoritic water line; LMWL, local meteoritic water line.

In the present study, the isotope signatures of precipitation are interpreted according to 1 year times series data. However, long-term monitoring of the local precipitation stable isotope signatures at the investigated site would be valuable for future similar studies.

$\delta^{2} \mathrm{H}$ vs. $\delta^{18} \mathrm{O}$ isotopic ratios are determined for 20 samples to validate the regional hydrogeochemical conceptual model. Each hydrogeological process presented in Section 4.3 is represented by at least four samples. When we compare the $\delta^{2} \mathrm{H}$ vs. $\delta^{18} \mathrm{O}$ ratios of the 20 groundwater samples to the LMWL and include the respective geochemical evolution processes for each sample (Figure 13), we observe calcium dissolution for groundwater samples with lower isotopic ratios; the values correspond to cooler conditions. Under such conditions, the concentration of $\mathrm{CO}_{2(\mathrm{aq})}$ increases to form carbonic acid, $\mathrm{H}_{2} \mathrm{CO}_{3}$, which decreases the $\mathrm{pH}$ of groundwater [27].

The groundwater samples dominated by freshening and water-rock interactions show relatively heavy isotopic ratios (Figure 13). The $\delta^{2} \mathrm{H}$ of samples undergoing freshening varies between -82.3 and -66.4 , and the $\delta^{18} \mathrm{O}$ varies from -12.3 to -10.0 . Samples strongly influenced by water-rock interactions have $\delta^{2} \mathrm{H}$ values varying between -84.1 and -72.9 and $\delta^{18} \mathrm{O}$ values ranging between -12.3 and -10.8 . The volume of freshwater able to be mixed with seawater is greater during the early spring/late summer, a warmer period of the year characterized by heavier isotopes. Recharge area samples have $\delta^{2} \mathrm{H}$ values between -93.2 and -79.0 and $\delta^{18} \mathrm{O}$ values from -13.2 to -11.8 . Finally, samples experiencing calcite dissolution present relatively lower isotopic ratios, i.e., $\delta^{2} \mathrm{H}$ varying from -97.5 to -84.8 and $\delta^{18} \mathrm{O}$ varying from -13.7 to -12.7 . These isotopic results suggest that the physicochemical parameters of groundwater, such as temperature, have a greater impact on hydrogeochemical processes affecting groundwater chemistry than the immediate geological environment, e.g., bedrock geology. 


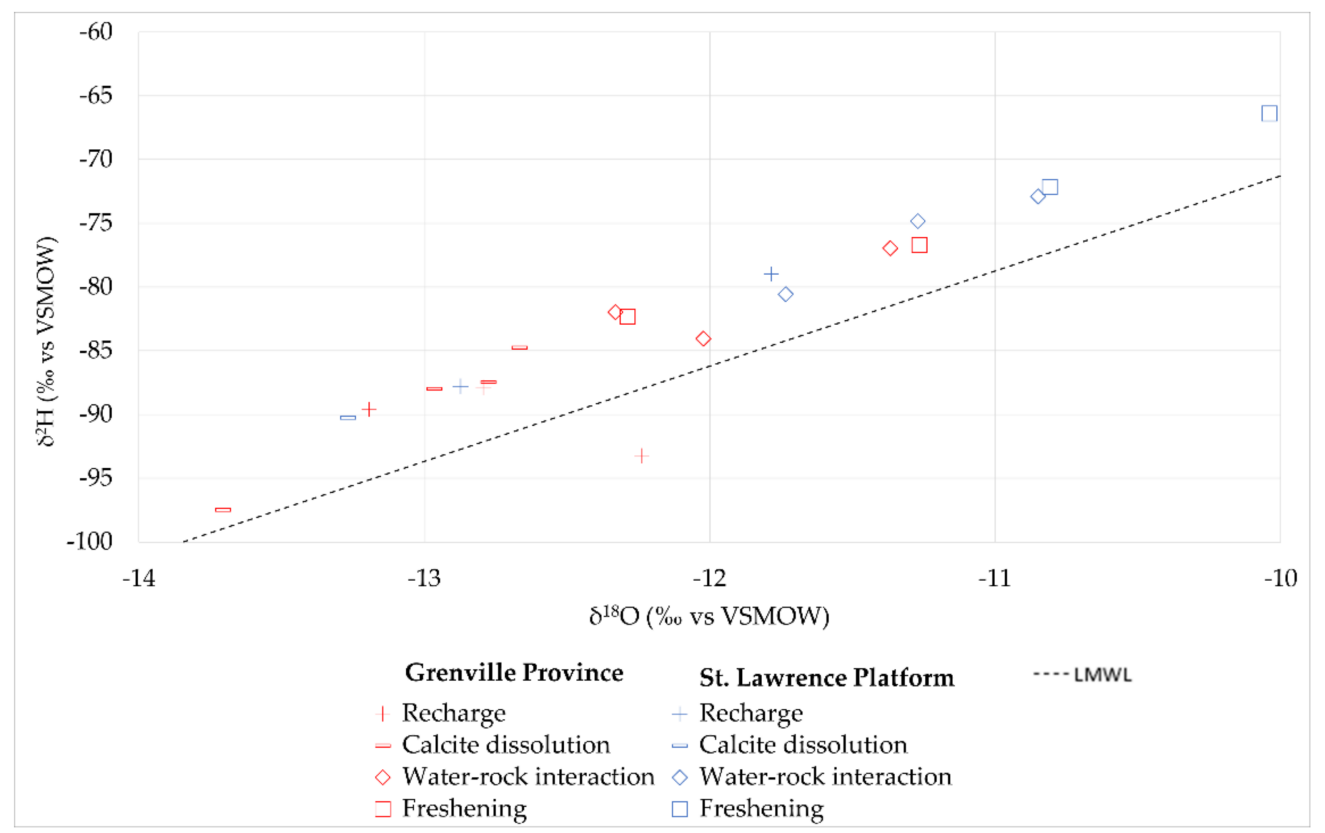

Figure 13. Binary diagram of $\delta^{2} \mathrm{H}$ vs. $\delta^{18} \mathrm{O}$ for 20 samples from the Grenville Province and St. Lawrence Platform. The dashed line represents the local meteoritic water line (LMWL).

\section{Conclusions}

In this study, the influence of the geological context on the chemical evolution of groundwater was investigated in the Lanaudière and Eastern Mauricie administrative regions of Quebec, two areas that cover portions of two geological provinces, i.e., the Grenville Province (crystalline rocks) and St. Lawrence Platform (sedimentary rocks), both covered by glacial and glaciomarine sediments (ca. 80,000 year BP to 11,000 year BP). We undertook chemical analyses of inorganic chemical constituents (major and trace elements) and stable water isotopes $\left(\delta^{2} \mathrm{H}\right.$ and $\left.\delta^{18} \mathrm{O}\right)$ on groundwater samples and then used bivariate plots, statistical analyses, and geochemical modeling methods to determine the key controls on groundwater evolution within each region.

The outcomes of this study are presented in the form of a conceptual model of groundwater geochemical evolution. In the study area, groundwater chemical evolution is mainly governed by four hydrogeochemical mechanisms regardless of the specific geology of the geological provinces: (i) precipitation infiltrating the recharge areas, (ii) carbonate and silicate dissolution by freshwater, (iii) $\mathrm{Ca}^{2+} / \mathrm{Na}^{+}$cation exchange through water-rock interactions, and (iv) $\mathrm{Ca}^{2+} / \mathrm{Na}^{+}$cation exchange through freshening. The fossil water of the Champlain Sea remains present in both regional aquifers (crystalline and sedimentary rocks) and is the main driver for groundwater chemical changes. The $\delta^{2} \mathrm{H}$ vs. $\delta^{18} \mathrm{O}$ isotopic ratios and the similar chemical composition of groundwater suggest that the physicochemical parameters of groundwater have a greater effect on hydrogeochemical mechanisms than the immediate geological environment.

However, we noted some differences in regard to minor elements at the local scale. We observed elevated concentrations of manganese in some groundwater samples in both the Grenville Province and St. Lawrence Platform. The presence of organic matter decreases the oxygen rate in groundwater, creating a reductive environment that accelerates the solubilization of manganese. Some groundwater samples collected from the sedimentary rock aquifers of the St. Lawrence Platform also revealed an excess of sulfide. This sulfide likely originated from either the anaerobic degradation of organic materials containing sulfide or by the incursion of natural gas. Some deeper wells in the Grenville Province had high fluoride concentrations. The local geology at these wells appears to be the main source of fluoride in groundwater as the local bedrock is composed of tonalitic and trondhjemitic 
gneiss. Therefore, minor elements in addition to major elements make it possible to improve our understanding of how the geological context affects groundwater chemistry.

This study not only characterizes the natural groundwater quality of our study area but also contributes to a better understanding of groundwater chemical evolution within aquifers belonging to two different geological contexts. Our results can be used to elaborate effective groundwater resource management/protection strategies by identifying areas with high salinity contamination. Nonetheless, expanded knowledge of the lithology of the stratigraphic units within the Lanaudière and Eastern Mauricie aquifers would improve our understanding of the relationship between groundwater chemistry and aquifer geology using trace elements that appear to be better tracers of geological influence on groundwater chemistry than major elements.

Author Contributions: Conceptualization, R.T. and J.W.; Methodology, R.T. and J.W.; Software, R.T.; Validation, J.W. and R.C.; Formal Analysis, R.T., J.W. and R.C.; Investigation, R.T. and J.W.; WritingOriginal Draft Preparation, R.T.; Writing—Review and Editing, J.W., R.C. and L.B.; Supervision, J.W. and R.C.; Project Administration, J.W. and R.C.; Funding Acquisition, J.W. and R.C. All authors have read and agreed to the published version of the manuscript.

Funding: This research was funded by the Fondation de l'Université du Québec à Chicoutimi and by Ministère de l'Environnement et de la Lutte contre les Changements Climatiques (MELCC) by the Programme d'Acquisition des Connaissances sur les Eaux Souterraines of Quebec (PACES).

Data Availability Statement: The study did not report any data.

Acknowledgments: The authors would like to thank all the undergraduate students and field assistants for their help during the fieldwork. The authors also thank the local populations of the Lanaudière and Eastern Mauricie regions who provided free access to their private wells during fieldwork.

Conflicts of Interest: The authors declare that they have no conflict of interest.

\section{References}

1. Ministère de l'Environnement et de la Lutte Contre les Changements Climatiques: Projets D'acquisition de Connaissance des eaux souterraines. Available online: https://www.environnement.gouv.qc.ca/eau/souterraines/programmes/acquisitionconnaissance.htm (accessed on 9 March 2021).

2. Larocque, M.; Cloutier, V.; Levison, J.; Rosa, E. Results from the Quebec Groundwater Knowledge Acquisition Program. Can. Water Resour. J. 2018, 43, 69-74. [CrossRef]

3. Rouleau, A.; Larocque, M.; Walter, J.; Gagné, S.; Tremblay, L.; Germaneau, D. Le programme d'acquisition de connaissances sur les eaux souterraines. Vecteur Environ. 2012, 45, 30-31.

4. Tòth, J. Groundwater as a geologic agent: An overview of the causes, processes, and manifestations. Hydrogeol. J. 1999, 7, 1-14. [CrossRef]

5. Chebotarev, I. Metamorphism of natural waters in the crust of weathering. Geochim. Cosmochim. Acta 1955, 8, 22-48. [CrossRef]

6. Beaudry, C.; Lefebvre, R.; Rivard, C.; Cloutier, V. Conceptual model of regional groundwater flow based on hydrogeochemistry (Montérégie Est, Québec, Canada). Can. Water Resour. J. 2018, 43, 152-172. [CrossRef]

7. Walter, J.; Rouleau, A.; Chesnaux, R.; Lambert, M.; Daigneault, R. Characterization of general and singular features of major aquifer systems in the Saguenay-Lac-Saint-Jean region. Can. Water Resour. J. 2018, 43, 75-91. [CrossRef]

8. Ghesquière, O.; Waler, J.; Chesnaux, R.; Rouleau, A. Scenarios of groundwater chemical evolution in a region of the Canadian Shield based on multivariate statistical analysis. J. Hydrol. Reg. Stud. 2015, 4, 246-266. [CrossRef]

9. Montcoudiol, N.; Molson, J.; Lemieux, J.-M. Groundwater geochemistry of the Outaouais Region (Québec, Canada): A regional study. Hydrogeol. J. 2015, 23, 377-396. [CrossRef]

10. Lacasse, K. Caractérisation Géochimique et Isotopique des Aquifères du Sud-Ouest de la Mauricie. Master's Thesis, Université du Québec à Trois-Rivières, Québec, QC, Canada, 2013.

11. Blanchette, D.; Lefebvre, R.; Nastev, M.; Cloutier, V. Groundwater quality, geochemical processes and groundwater evolution in the Chateauguay River watershed, Quebec, Canada. Can. Water Resour. J. 2010, 35, 503-526. [CrossRef]

12. Cloutier, V.; Lefebvre, R.; Savard, M.; Therrien, R. Groundwater origin and geochemical processes in the Basses-Laurentides sedimentary rock aquifer system, St. Lawrence Lowlands, Quebec, Canada. In Proceedings of the 57th Canadian Geotechnical Conference and 5th Joint CGS/IAH Conference, Québec City, QC, Canada, 24-26 October 2004; p. 8.

13. Walter, J.; Chesnaux, R.; Cloutier, V.; Gaboury, D. The influence of water/rock-water/clay interactions and mixing in the salinization processes of groundwater. J. Hydrol. Reg. Stud. 2017, 13, 168-188. [CrossRef] 
14. Walter, J.; Chesnaux, R.; Gaboury, D.; Cloutier, V. Subsampling of regional-scale database for improving multivariate analysis interpretation of groundwater chemical evolution and ion sources. Geosciences 2019, 9, 139. [CrossRef]

15. Ministère de l'Énergie et des Ressources naturelles. Portrait Territoriale Mauricie 2006, 87. Available online: https:/ / mern.gouv. qc.ca/nos-publications/portrait-territorial-mauricie/ (accessed on 3 December 2021).

16. Ministère de l'Énergie et des Ressources naturelles. Portrait Territoriale Lanaudière 2007, 96. Available online: https:/ /mern. gouv.qc.ca/nos-publications/portrait-territorial-lanaudiere/ (accessed on 3 December 2021).

17. Ministère des Affaires Municipales et Habitation: Organisation municipale—Région administrative 14: Lanaudière. Available online: https:/ / www.mamh.gouv.qc.ca/organisation-municipale/organisation-territoriale/regions-administratives/lanaudiere/ (accessed on 9 March 2021).

18. Ministère des Affaires Municipales et Habitation: Organisation Municipale—Région Administrative 04: Mauricie. Available online: https:/ / www.mamh.gouv.qc.ca/organisation-municipale/organisation-territoriale/regions-administratives/mauricie/ (accessed on 9 March 2021).

19. Bédard, J. Carte Géologique de la Région de Cartier-Tracy, Comtés de Montcalm, Joliette et Berthier; Ministère des Richesses Naturelles: Quebec, QC, Canada, 1971.

20. Béland, J.; Bergeron, R. Esquisse géologique du Québec méridional. Cah. Geogr. Que. 1959, 3, 131-138. [CrossRef]

21. Nadeau, L.; Brouillette, P. Structural Map of Trois-Rivières, Grenville Province, Québec; Map 1:250,000; Geological Survey of Canada: Ottawa, ON, Canada, 1995.

22. O'Nell, J.; Osborne, F. Géologie de la mine Tetreault, Montauban-les-mines, comté de Portneuf; (Carte No 496 associée au rpport No 136); Ministère des Mines et des Pêcheries: Québec, QC, Canada, 1938.

23. Comeau, F.-A.; Bédard, K.; Malo, M. Lithostratigraphie Standardisée du Basin des Basses-Terres du Saint-Laurent Basée sur L'étude des Diagraphies: Rapport Final; Research Report, R1442; INRS: Quebec City, QC, Canada, 2013.

24. Globensky, Y. Géologie des Basses-Terres du St-Laurent (Geology of the St. Lawrence Lowlands); Ministry of Energy and Resources, General Direction for Geologic and Mineral Exploration: Québec, QC, Canada, 1987; p. 85.

25. Cloutier, V.; Lefebvre, R.; Savard, M.; Therrien, R. Desalination of a sedimentary rock aquifer system invaded by Pleistocene Champlain Sea water and processes controlling groundwater geochemistry. Environ. Earth Sci. 2010, 59, 977-994. [CrossRef]

26. Ministère de l'Environnement et de la Lutte Contre les Changements Climatiques: Normales Climatiques du Québec 1981-2010. Available online: https://www.environnement.gouv.qc.ca/climat/normales/index.asp (accessed on 11 January 2021).

27. Appelo, C.A.J.; Postma, D. Geochemistry, Groundwater and Pollution, 2nd ed.; CRC Press: Boca Raton, FL, USA, 2005; 668p.

28. Hounslow, A. Water Quality Data: Analysis and Interpretation; CRC Press: Boca Raton, FL, 1995; p. 416.

29. Baillargeon, G. Probabilité et Statistique Avec Applications en Technologie et Ingénierie; Les Éditions SMG: Trois-Rivières, QC, Canada, 2002; p. 728.

30. Machiwal, D.; Cloutier, V.; Güler, C.; Kazakis, N. A review of GIS-integrated statistical techniques for groundwater quality evaluation and protection. Environ. Earth Sci. 2018, 77, 1-30. [CrossRef]

31. Davis, J.C.; Sampson, R.J. Statistics and Data Analysis in Geology; John Wiley and Sons, Inc.: Hoboken, NJ, USA, $1986 ;$ p. 646.

32. Güler, C.; Thyne, G.; McCray, J.; Turner, K. Evaluation of graphical and multivariate statistical methods for classification of water chemistry data. Hydrogeol. J. 2002, 10, 455-474. [CrossRef]

33. Cloutier, V.; Lefebvre, R.; Therrien, R.; Savard, M. Multivariate statistical analysis of geochemical data as indicative of the hydrogeochemical evolution of groundwater in a sedimentary rock aquifer system. J. Hydrol. 2008, 353, 294-313. [CrossRef]

34. Farnham, I.; Johannesson, K.; Singh, A.; Hodge, V.; Stetzenbach, K. Factor analytical approaches for evaluating groundwater trace element chemistry data. Anal. Chim. Acta 2003, 490, 123-138. [CrossRef]

35. Yeomans, K.; Golder, P. The Guttman-Kaiser criterion as a predictor of the number of common factors. Statistician 1982, 221-229. [CrossRef]

36. RStudio Team. RStudio: Integrated Development for R. RStudio, PBC, Boston. 2019. Available online: http:/ / www.rstudio.com/ (accessed on 5 January 2020).

37. Parkhurst, D.L.; Appelo, C.A.J. User's guide to PHREEQC (Version 2): A computer program for speciation, batch-reaction, one-dimensional transport, and inverse geochemical calculations. Water-Resour. Investig. Rep. 1999, 99, 312.

38. Health Canada. Guidelines for Canadian Drinking Water Quality_Guideline Technical Document-Total Dissolved Solids (TDS); Water and Air Quality Bureau, Healthy Environments and Consumer Safety Branch, Health Canada: Ottawa, ON, Canada, 1991 ; p. 3.

39. Occhietti, S.; Richard, P. Effet réservoir sur les âges 14C de la Mer de Champlain à la transition Pléistocène-Holocène: Révision de la chronologie de la déglaciation au Québec méridional. Géographie Phys. Quat. 2003, 57, 115-138. [CrossRef]

40. Hem, J.D. Study and Interpretation of the Chemical Characteristics of Natural Water, 3rd ed.; Library of Congress, Department of the Interior, US Geological Survey: Washington, DC, USA, 1985; p. 272.

41. Datta, P.; Tyagi, S. Major ion chemistry of groundwater in Delhi area: Chemical weathering processes and groundwater flow regime. J. Geol. Soc. India 1996, 47, 179-188.

42. Plummer, L.; Busby, J.; Lee, R.; Hanshaw, B. Geochemical modeling of the Madison aquifer in parts of Montana, Wyoming, and South Dakota. Water Resour. Res. 1990, 26, 1981-2014. [CrossRef]

43. Langmuir, D. The geochemistry of some carbonate groundwaters in central Pennsylvania. Geochim. Cosmochim. Acta 1971, 35, 1023-1045. [CrossRef] 
44. Piper, A.M. A graphic procedure in the geochemical interpretation of water-analyses. Eos Trans. Am. Geophys. Union 1944, 25, 914-928. [CrossRef]

45. Goldberg, E.; Broecker, W.; Gross, M.; Turekian, K. Radioactivity in the Marine Environment; National Academyof Sciences: Washington, DC, USA, 1971; p. 137.

46. Gibbs, R.J. Mechanisms controlling world water chemistry. Science 1970, 170, 1088-1090. [CrossRef] [PubMed]

47. Kim, J.; Kim, K.; Thao, N.; Batsaikhan, B.; Yun, S. Hydrochemical assessment of freshening saline groundwater using multiple end-members mixing modeling: A study of Red River delta aquifer, Vietnam. J. Hydrol. 2017, 549, 703-714. [CrossRef]

48. Health Canada. Guidelines for Canadian Drinking Water Quality-Summary Table; Water and Air Quality Bureau, Healthy Environments and Consumer Safety Branch, Health Canada: Ottawa, ON, Canada, 2020; p. 28.

49. Hou, Q.; Zhang, Q.; Huang, G.; Liu, C.; Zhang, Y. Elevated manganese concentrations in shallow groundwater of various aquifers in a rapidly urbanized delta, south China. Sci. Total Environ. 2020, 701. [CrossRef] [PubMed]

50. Bondu, R.; Cloutier, V.; Rosa, E. Occurrence of geogenic contaminants in private wells from a crystalline bedrock aquifer in western Quebec, Canada: Geochemical sources and health risks. J. Hydrol. 2018, 55, 627-637. [CrossRef]

51. Li, X.; Masuda, H.; Kusakabe, M.; Yanagisawa, F.; Zeng, H. Degradation of groundwater quality due to anthropogenic sulfur and nitrogen contamination in the Sichuan Basin, China. Geochem. J. 2006, 40, 309-322. [CrossRef]

52. Delisle, C.; Schmidt, J. The effects of sulphur on water and aquatic life in Canada. The effects of sulphur on water and aquatic life in Canada. In Sulphur and Its Inorganic Derivatives in the Canadian Environment; NRCC No. 15015; Associate Committee on Scientific Criteria for Environmental Quality, National Research Council of Canada: Ottawa, ON, Canada, 1977.

53. Pinet, N.; Duchesne, M.; Lavoie, D.; Bolduc, A.; Long, B. Surface and subsurface signature of gas seepage in the St. Lawrence Estuary (Canada): Significance to hydrocarbon exploration. Mar. Pet. Geol. 2008, 25, 271-288. [CrossRef]

54. Castonguay, C.; Lavoie, D.; Dietrich, J.; Laliberté, J.-Y. Structure and petroleum plays of the St. Lawrence Platform and Appalachians in southern Quebec: Insights from interpretation of MRNQ seismic reflection data. Bull. Can. Pet. Geol. 2010, 58, 219-234. [CrossRef]

55. Moritz, A.; Hélie, J.-F.; Pinti, D.L.; Larocque, M.; Barnetche, D.; Retailleau, S.; Lefebvre, R.; Gélinas, Y. Methane baseline concentrations and sources in shallow aquifers from the shale gas-prone region of the St. Lawrence lowlands (Quebec, Canada). Environ. Sci. Technol. 2015, 49, 4765-4771. [CrossRef] [PubMed]

56. Ladevèze, P.; Rivard, C.; Lavoie, D.; Séjourné, S.; Lefebvre, R.; Bordeleau, G. Fault and natural fracture control on upward fluid migration: Insights from a shale gas play in the St. Lawrence Platform, Canada. Hydrogeol. J. 2019, 27, 121-143. [CrossRef]

57. Richardson, J.; Blenkinsop, J. Dissolution of fluorite $\left(\mathrm{CaF}_{2}\right)$ for geochemistry. J. Fluor. Chem. 1989, 43, 145-149. [CrossRef]

58. Guilleux, C.; Kochoni, E.; Campbell, P.; Blais, J.; Fortin, C. Géochimie et Écotoxicologie Des. Fluorures Dans les Écosystèmes Terrestres et Aquatiques et Méthodes de Traitement: Revue de la Littérature Scientifique; Research Report R1640; INRS, Centre Eau Terre Environnement: Québec, QC, Canada, 2015; p. 116.

59. Rankama, K.; Edgington, G. Fluorine in soils. Soil Sci. 1946, 61, 341-353. [CrossRef]

60. Leng, M. Isotopes in palaeoenvironmental research. Dev. Paleoenviron. Res. 2006, 10, 307. [CrossRef] 